\title{
SAN PETERSBURGO, UNA CIUDAD CREATIVA \\ EN TIEMPOS DEL ZAR ALEJANDRO I. LA APORTACIÓN A LA ARQUITECTURA Y AL URBANISMO \\ DEL INGENIERO ESPAÑOL AGUSTÍN DE BETANCOURT
}

\author{
María Jesús Pozas* \\ Universidad de Deusto
}

\section{RESUMEN}

El objetivo de este trabajo consiste en ofrecer un nuevo enfoque sobre el ingeniero, arquitecto e inventor español Agustín de Betancourt (1758-1824) desde una perspectiva global dentro del contexto histórico de la Ilustración y la Revolución Industrial. Analizaremos su perfil personal y profesional, así como la relación compleja que mantuvo con el zar Alejandro I entre 1808 y 1824 . Contribuyó al desarrollo urbano, industrial y cultural de Rusia, y en especial de San Petersburgo, que se convirtió en las primeras décadas del siglo xix en uno de los núcleos urbanos más espléndidos y armoniosos de Europa. Rusia fue su patria de adopción, donde tuvo que exiliarse por motivos profesionales y políticos, pero siempre se mantuvo unido a sus orígenes canarios hasta su muerte. Se le consideró uno de los mejores ingenieros de la Europa de su tiempo, y con él nació la ingeniería civil en España y en Rusia, donde se le considera un héroe.

Palabras clave: Agustín de Betancourt, España, ingeniero, Alejandro I, San Petersburgo, Rusia, urbanismo, arquitectura.

\section{ST. PETERSBURG, A CREATIVE CITY IN TIME OF TSAR ALEXANDER I: THE CONTRIBUTION TO URBAN PLANNING AND THE ARCHITECTURE OF THE SPANISH ENGINEER AGUSTÍN DE BETANCOURT}

\begin{abstract}
The objective of this study is to offer a new approach to the Spanish engineer, architect, and inventor Agustín de Betancourt (1758-1824), from a global perspective within the historical context of the Enlightenment and the Industrial Revolution. We will analyze his personal and professional profile, as well as the complex relationship that remained with the Tsar Alexander I between 1808 to 1824 . He contributed to the urban planning, industrial, and cultural development of Russia, and specially of St. Petersburg, that became the first decades of the $19^{\text {th }}$ century in one of the most splendid and harmonious European towns. Russia was his adoption country where he had to go into exile due professional and political reasons, but he always remained attached to his Canary Islands origins until his death. $\mathrm{He}$ was considered one of the best engineers in the Europe of his time, and with him was born civil engineering in Spanish and Russian where he is considered a hero.
\end{abstract}

Keywords: Agustín de Betancourt, Spain, engineer, Alexander I, San Petersburg, Russian, urban planning, architecture. 


\section{INTRODUCCIÓN}

En este lugar el destino nos manda que construyamos una ventana sobre Europa. Pedro el Grande, 16 de mayo de 1703.

Cuando Pedro el Grande fundó la ciudad de San Petersburgo en 1703 en la isla Zaiachi (isla de los conejos), era una ciudad imposible, situada en el pantanoso delta del río Neva, en un espacio natural de gran fragilidad ecológica. Pero lo que nos importa no es descubrir las razones geopolíticas que le llevaron al cuarto Romanov a construir esta ciudad y convertirla en el centro del poder y en la capital del Imperio, siendo "la ciudad más artificial del mundo» como la definía Dostoevski, sino que el objetivo de este trabajo consiste en hacer un recorrido por la historia, el pensamiento, la arquitectura y el arte de San Petersburgo ${ }^{1}$. Además, en esta investigación pretendemos saber cómo se transformó la ciudad durante el reinado del zar Alejandro I (1777-1825) para reconocer la imagen que proyecta hoy día, y el papel que desempeñó el gran ingeniero, arquitecto e inventor español Agustín de Betancourt y Molina (1758-1824) en relación con su aportación al desarrollo urbanístico y arquitectónico de San Petersburgo y con otras obras que realizó en Rusia ${ }^{2}$. Partiremos de la idea del escritor italiano Italo Calvino, que afirmaba que «las ciudades son un conjunto de muchas cosas: memorias, deseos, signos de un lenguaje, recuerdos ${ }^{3}$. Todo eso y más es San Petersburgo.

El zar Alejandro I, de la dinastía Romanov, rey de Polonia y gran duque de Finlandia a partir de 1815, nació el 12 de diciembre de 1777 en San Petersburgo, hijo del emperador Pablo I y de la princesa alemana Sofía de Württemberg, y nieto predilecto de Catalina II la Grande. Alejandro I declaró en su primer manifiesto del 13 de marzo de 1801 que asumía la obligación de gobernar al pueblo ruso «según

* Universidad de Deusto, Bilbao. Conferencia pronunciada el 11 de octubre de 2018 en el Instituto de Historia de la Universidad Estatal de San Petersburgo.

${ }^{1}$ Quiero agradecer a las siguientes personas la ayuda prestada. Al cónsul general de España en San Petersburgo, don Felix Valdés Valentín Gamazo, por el apoyo generoso que me ha brindado, y por su contribución en la presentación de la conferencia sobre Agustín de Betancourt que pronuncié en el Instituto de Historia de la Universidad Estatal de San Petersburgo el 11 de octubre de 2018. Muy agradecida al director del Departamento de Historia Moderna del Instituto de Historia de la Universidad Estatal de San Petersburgo, doctor Vladimir Nikolaevich Baryshnikov. A la profesora Tatiana Markicha, del mismo Departamento, por su amable atención en la publicación de la conferencia en la Revista de Historia de la Universidad Estatal de San Petersburgo. Mi gratitud a Alexandra Asonoba por la traducción de la conferencia al ruso. Deseo expresar un reconocimiento especial a don Juan Cullen Salazar por su valiosa colaboración, por proporcionarme una excelente información, y sobre todo por brindarme su amistad. Mi agradecimiento final corresponde a la doctora Clementina Calero Ruiz, directora de la Revista de Historia Canaria de la Universidad de La Laguna (Tenerife), por aceptar esta publicación generosamente. Asimismo, doy las gracias a todos los que me han ayudado en esta investigación.

${ }_{2}$ Este trabajo es una ampliación de otro publicado con el mismo título en la Revista del Instituto de Historia de la Universidad Estatal de San Petersburgo, n. ${ }^{\circ} 18$ (2), 2018, pp. 66-98.

${ }^{3}$ Italo Calvino (2017): Las ciudades invisibles. Siruela: Madrid, p. 15. 
las leyes y el corazón de mi sabia abuela» ${ }^{4}$. Desde los primeros ańos de su reinado (1801-1825) llevó a cabo una serie de reformas políticas como la reorganización de la Hacienda, fomentó la educación, mejoró la suerte de los siervos, declaró libre el ejercicio de varias profesiones, protegió la industria, el comercio, y ordenó reorganizar las universidades; estableció institutos pedagógicos en San Petersburgo y Moscú, y fundó escuelas de primera y segunda enseñanza, pues hay que tener presente que al comenzar el siglo xix, Rusia era abrumadoramente rural, agrícola y autócrata. Para lograr estos objetivos se rodeó de un equipo de consejeros que se inspiraban en las instituciones inglesas.

Dentro de este contexto se llevó a cabo una serie de reformas urbanas destinadas a mejorar la seguridad y el control de la ciudad de San Petersburgo. Pero esta política urbanística no se redujo a la arquitectura, sino que también tuvieron un papel destacado las infraestructuras en la modernización de San Petersburgo. Alejandro I quería que la capital del Imperio estuviese a la altura de las grandes ciudades europeas (París y Londres) siguiendo la tradición de sus predecesores de la dinastía Romanov, en especial la labor desarrollada por su abuela Catalina II la Grande, que miró hacia Europa más que ninguna otra zarina con el fin de occidentalizar la ciudad y engrandecerla frente a la "asiática Moscú», para convertirla en una de las ciudades más bellas del mundo. En este sentido conviene recordar la frase del último zar de Rusia, Nicolás II, a quien le gustaba advertir a sus invitados que «San Petersburgo estaba en Rusia, pero no era Rusia»" ${ }^{6}$.

El urbanismo y la arquitectura de San Petersburgo evolucionaron a lo largo del siglo XVIII a través de diversos estilos desde el triunfo del Barroco, pasando por el Rococó hasta el Neoclasicismo del reinado de Alejandro I, llamado también «estilo alejandrino». A partir de la década 1770 hasta 1810 llegaron a San Petersburgo importantes arquitectos italianos que realizaron notables proyectos de estilo «neoclásico» como el teatro del Hermitage, entre los que hay que destacar a Giacomo Quarenghi, y el francés Auguste de Montferrand, que bajo la supervisión del ingeniero español Agustín de Betancourt ejecutó la construcción de la catedral de San Isaac entre 1818 y 18587. A la vez que arquitectos rusos diseñaron la catedral de Kazán, inspirada en la basílica de San Pedro de Roma, en la Nevski Prospekt, la principal arteria urbana de San Petersburgo. En la etapa «alejandrina» se diseñó el corazón histórico de San Petersburgo, formado por tres plazas: la plaza del Palacio

${ }^{4}$ Sydney Wayne, Jackman (ed.) (1969): Romanov Relations: the Private Correspondence of Tsar Alexandr I, Nicholas I and the Grand Dukes Contantine and Michael with their Sister Queen Anna Pavlovna. McMillan: Londres; Simon Sebag Montefiore. 2018. Los Romanov: 1616-1918. Editorial Crítica: Madrid.

5 VV. AA. (1991): Enciclopedia Universal Ilustrada Europea-Americana. Espasa Calpe: Madrid, tomo. 4, pp. 403-404.

6 Warnes, David (1999): Chronicle of the Russian Tsars. Thames-Hudsson: Londres; https:// historiaybiografias.com/sanpetersburgo/.

${ }^{7}$ Biblioteca Pública de San Petersburgo. Sección de Manuscritos. Journal des travaux de l'Église d'Isaac; Montferrand, Auguste de (1845): L'Église cathédrale de Saint-Isaac, description arquitecturale, pittoresque et historique. San Petersburgo. 
de Invierno, centro del Imperio; la plaza del Senado, actualmente denominada de los Decembristas, centro administrativo; y la plaza de San Isaac, centro religioso ${ }^{8}$.

En este trabajo pondremos de relieve un nuevo enfoque sobre el prestigioso ingeniero militar español Agustín de Betancourt al cumplirse el 260 aniversario de su nacimiento, desde una perspectiva global dentro del contexto histórico que le tocó vivir, como fue la Espańa ilustrada de la segunda mitad del siglo xviII, la Francia revolucionaria y napoleónica, la Inglaterra de la Revolución Industrial y la Rusia del primer cuarto del siglo XIX entre el periodo progresista y el reaccionario del reinado de Alejandro I. Betancourt había nacido el 1 de febrero de 1758 en la ciudad del Puerto de la Cruz, en la isla de Tenerife, pertenecía a una de las familias más distinguidas de las Islas tanto por la parte paterna como por la materna, que estaba entroncada con la nobleza local; falleció el 14 de julio de 1824 en San Petersburgo según el calendario juliano. ${ }^{9}$ Analizaremos su perfil personal y profesional, así como la relación compleja que mantuvo con el zar Alejandro I entre 1808 y 1824, desde el paradigma de la «Historia de las Mentalidades» para acercarnos a las formas de pensar, sentir y amar en general de estos dos personajes, y desde la metodología de la «Historia Comparada» ${ }^{10}$.

El trabajo que desarrolló Betancourt a lo largo de su carrera abarcó diferentes campos, desde las máquinas de vapor y los globos aerostáticos hasta la ingeniería estructural y los planteamientos urbanísticos. Por otra parte, nos ocuparemos de las obras que realizó en San Petersburgo como ingeniero, arquitecto, urbanista y constructor, para transformarla en uno de los núcleos urbanos más espléndidos y armoniosos de Europa; destacaremos su importante participación en la construcción de la catedral de San Isaac, convertida actualmente en uno de los iconos de la ciudad; en este sentido diseñó un nuevo urbanismo y estuvo al frente de la construcción de las modernas infraestructuras, y llevó a cabo importantes trabajos en la isla de Kronstadt; además de otras obras significativas que realizó en Rusia, como la planificación y la construcción de la Feria de Nizhni Nóvgorod, que fue su gran obra, y la Sala de Ejercicios Ecuestres de Moscú (Manezh); así como un nuevo sistema de canalización y bulevares que puso en marcha en la ciudad de Tver para luchar contra las crecidas del río Volga, y otras construcciones más, fue el caso de la reforma de la fábrica de armas de Tula mediante la instalación de una máquina de vapor, y la de cańones de Kazán ${ }^{11}$.

${ }^{8}$ Mazour, Anatole (1937): First Russian Revolution, 1825. Stanford University Press: Stanford; Russell Sherman\& Robert Pearce (2002): Russia 1815-1881. Hodder \& Stoughton: London.

9 González Tascón, Ignacio (dir.) (1996): Betancourt. Los inicios de la ingeniería moderna en Europa. CEHOPU: Madrid.

${ }_{10}$ Sobre la Historia de las Mentalidades existe una amplia historiografía, véase como ejemplo Duby, Georges (1961): «L'Histoire des mentalités». L'Histoire et ses méthodes. Gallimard: Paris; Le Goff, Jacques: «Les mentalités: une histoire ambiguë». Le Goff, Jacques y Nora, Pierre (dir.) (1974): Faire de l'histoire, vol. III. Gallimard: Paris, pp. 76-94.

${ }^{11}$ Bogoliubov, Aleksei y García-Diego, José A. (1986): «Agustín de Betancourt como arquitecto y urbanista». LLULL, vol. 9, pp. 35-54. 
También llevó a cabo importantes estudios y trabajos sobre el desarrollo de las redes de comunicación entre las diferentes regiones de Rusia en el ámbito viario y fluvial con la construcción de puentes, canales y esclusas; además de la ejecución de destacadas obras públicas para mejorar las infraestructuras portuarias, y creó empresas hidráulicas para la desecación y saneamiento de terrenos, la limpieza de los fondos de los ríos y canales; inventó la primera máquina de vapor para barcos fluviales en Rusia e introdujo los barcos de vapor para navegar en los ríos rusos. De igual modo se ocupó del proyecto de ferrocarriles en Rusia, y en 1813 fundó el «Museo del Ferrocarril» con instrumentos que se habían fabricado en los talleres del Instituto de Vías de Comunicación ${ }^{12}$.

Dentro de la obra civil hay que destacar su participación en la construcción de la primera carretera importante de Rusia entre San Petersburgo-NovgorodMoscú. Todas estas obras surgieron de las iniciativas reformistas del zar Alejandro I en el ámbito del "progreso ilustrado" y de las grandes invenciones y aportaciones prácticas de Agustín de Betancourt. Por otra parte, Agustín de Betancourt fundó en San Petersburgo el Instituto de Vías de Comunicación, Puentes y Canales en 1809, que se convirtió en uno de los mejores centros docentes de Europa. Además, fue nombrado director general del Cuerpo de Ingenieros de la Comunicación Interior y dirigió el Departamento de Vías de Comunicación hasta su muerte, dentro del clima cultural e intelectual de las reformas ilustradas. El periodo ruso en el que desarrolló su brillante carrera abarca desde octubre de 1808 a 1820 , y a partir del viaje que realizó por la Rusia imperial desde el 27 de agosto de 1820 hasta diciembre del mismo año se produjo su declive, que se acentuó entre 1821 y 1824 al perder el favor de zarr $^{13}$.

Precisamente Agustín de Betancourt fue considerado uno de los mejores ingenieros de la Europa de su tiempo, y es conocido como el «ingeniero universal». Poseía grandes valores y una extraordinaria formación científica, como puede comprobarse por sus publicaciones y a través de la correspondencia familiar que mantuvo con sus padres y hermanos, que nos revela muchos aspectos de su personalidad, su valía personal, su generosidad y honestidad, la prudencia, el amor a la familia y la defensa de la libertad individual y colectiva; las cartas muestran bocetos de los relatos de su vida tanto personal como familiar y profesional. En total se conservan 18 cartas, la primera se la envió a su padre en la ciudad de La Orotava desde Madrid el 16 de agosto de 1780, cuando estaba estudiando en los Reales Estudios de San Isidro y en la Real Academia de San Fernando, en esa fecha tenía 22 ańos. La última está escrita en San Petersburgo el 26 de diciem-

12 Bogoliubov, Aleksei (1973): Un héroe español del progreso: Agustín de Betancourt. Seminarios y Ediciones: Madrid; https://es.wikipedia.org/wiki/ Red_ferr...

${ }^{13}$ http://fundacionorotava.es/. biography; Tous Meliá, Juan y López Solano, César (2000): Guia histórica del museo Militar Regional de Canarias. Ministerio de Defensa, Secretaría General Técnica: Santa Cruz de Tenerife, pp. 79-80; García Ormaechea, Pedro: «Agustín de Betancourt, su juventud y vejez». El Día. Santa Cruz de Tenerife. 8 de agosto de 1974, y el Archivo Fernando J. del Hoyo Monteverde [AFJHM]. 
bre de 1822 con 64 años, casi al final de su vida, pues fallecería dos años más tarde; iba dirigida a su hermana Catalina de Betancourt y a su marido, Antonio Monteverde Rivas, en La Orotava. Estas cartas nos ayudan a comprender una parte importante de su vida, en ellas explicaba las razones de la toma de decisiones sobre asuntos fundamentales. Todos estos documentos privados se hallan en el "Archivo de la Familia Betancourt-Castro» en la ciudad de La Orotava, en la isla de Tenerife, de donde era originario ${ }^{14}$. Existe también una importante documentación sobre sus obras e inventos en los Archivos de Tenerife, Madrid, Londres, París y San Petersburgo, en los que se han reunido documentos originales ${ }^{15}$.

Agustín de Betancourt no es especialmente conocido en España, por lo que estamos en deuda con este gran ingeniero e inventor a pesar de los esfuerzos encomiables que se han realizado últimamente para dar a conocer su figura; en cambio, en Rusia ha merecido un gran reconocimiento, si bien es cierto que después de caer en desgracia con el emperador se silenció durante años su labor en Rusia, pero debido a las «Memorias» de su secretario Filipp Filíppovich Vigel, recuperó el honor que le correspondía por haber llevado a Rusia a un alto nivel de modernización tecnológica equiparable a las potencias europeas ${ }^{16}$. De la biografía de Agustín de Betancourt se han ocupado diversos autores de diferentes disciplinas; la primera se publicó en 1826-1828, en el número uno de la Revista de Vías de Comunicación, un proyecto de Betancourt, en la que se incluía un artículo por el coronel Jean Résimont sobre la vida y obra de Betancourt a modo de necrológica y un retrato suyo ${ }^{17}$. Otra de las primeras biografías fue la publicada en el Eco del Comercio un periódico local de Santa Cruz de Tenerife, y está fechada en febrero de 1859 y firmada por Aurelio Pérez Zamora ${ }^{18}$. Hay que añadir la titulada «Apuntes para la

14 Cullen Salazar, Juan (2008): La familia de Agustin de Betancourty Molina. Correspondencia intima. Domibari Editores: Las Palmas de Gran Canaria. El autor de esta obra es el depositario y gran conocedor del "Archivo de los Herederos de la Familia Betancourt-Castro" [AHBC] en la ciudad de La Orotava (Tenerife), en el que se hallan 43 cartas escritas por Agustín de Betancourt a sus padres y hermanos desde Madrid, París y San Petersburgo. Las citas de las cartas del «Archivo de los Herederos Betancourt-Castro» que se utilizan en este trabajo están tomadas básicamente de la obra de Juan Cullen Salazar. Estas cartas constituyen una fuente excepcional para penetrar en la vida familiar de esta figura universal del campo de la ciencia a nivel mundial y para aproximarnos a la sociedad de la época. Juan Cullen Salazar explora la faceta más íntima de Agustín de Betancourt a través de las cartas, que nos describen aspectos de su vida que transcurrieron paralelos a la labor científica que le otorgó el reconocimiento internacional en plena Ilustración.

${ }^{15}$ https://elpais.com>cultura. «España y Rusia se unen para recordar al ingeniero ilustrado Agustín de Betancourt», en El País», 26 de marzo de 1996.

16 Vigel, Filipp (2003): Memorias. Ed. Zajarov: Moscú, 2 vols. Filipp F. Vigel (17861856) se hizo famoso debido a su trabajo como secretario de Agustín de Betancourt y a sus «Memoria». Conocía a muchos escritores rusos como a Aleksandr Sergueyevich Pushkin, Nikolái Aramzín, Nikolái Gogol, Pyotr Andreyevich Vyazemsky, Iván Serguéyevich Turguéniev, Vasili Andréyevich Zhukovski, y a muchas personas de la época de Betancourt.

${ }^{17}$ http://fundacionorotava.es/. biography 14.

18 PAdrón Acosta, Sebastián (1958): El ingeniero canario don Agustín de Béthencourt Molina (1758-1824). Instituto de Estudios Canarios: La Laguna, Tenerife, pp. 11-12. 
biografía de Don Agustín de Béthencourt y Molina», escrita por su sobrino José de Bethencourt y Castro en $1842^{19}$.

Después de esta obra se produjo un largo silencio durante mucho tiempo; por ejemplo, en los oscuros años cuarenta y cincuenta del siglo pasado durante el franquismo la historiografía abandonó las investigaciones sobre los siglos XVIII y XIX, frente a la historiografía oficial acientífica y al servicio de la ideología del régimen que quería borrar estos siglos de la historia por ilustrados, liberales, anticatólicos y masónicos; en este ámbito Agustín de Betancourt fue un total desconocido porque se le consideraba un ilustrado y un antipatriota al haber estado al servicio de Rusia; además de ser liberal, y supuestamente masón, aunque esto último no podemos probarlo, tan sólo se publicaron unas pocas obras entre los ańos cincuenta y setenta. Habrá que esperar a finales del siglo xx y las primeras décadas del XxI para recuperar su figura principalmente desde Rusia, donde sigue estando muy presente ${ }^{20}$.

En los últimos años se han editado numerosos trabajos tanto en España como en Rusia, contamos con cinco biografías importantes, las de los historiadores españoles Antonio Rumeu de Armas, Sebastián Padrón Acosta, José Antonio García Diego, Amílcar Martín Molina, y las de Aleksei Bogoliúbov, y Alejandro Cioranescu, a las que hay que ańadir la reciente obra de Dmitry Kuznetsov ${ }^{21}$. Así mismo existen dos fundaciones en Espańa que tienen como finalidad dar a conocer la labor de Agustín de Betancourt; una es la «Fundación Canaria Orotava de Historia de la Ciencia», constituida en 1999, en la que se trabaja sobre el «Proyecto Betancourt» y se ha digitalizado la mayor parte de su obra ${ }^{22}$, y la otra es la «Fundación Betancourt», establecida en 1977 en la Escuela Técnica Superior de Ingenieros

19 Bethencourt y Castro, José (1842): Noticias biográficas de Don Agustín de Betancourt y Molina. La Orotava de Tenerife.

${ }^{20}$ Ribagorda Esteban, Álvaro (2001): «La fractura de la historiografía española durante la postguerra franquista». Cuadernos de Historia Contemporánea. Número 23, pp. 337-383.

${ }^{21}$ Rumeu de Armas, Antonio (1968): Agustin de Betancourt, fundador de la Escuela de Caminos y canales, nuevos datos biográficos. Colegio de Ingenieros de Caminos, Canales y Puertos: Madrid; Padrón Acosta, Sebastián (1958): El ingeniero canario don Agustín de Béthencourt Molina (17581824). Instituto de Estudios Canarios: La Laguna, Tenerife; García Diego, José Antonio (1985): En busca de Betancourt y Lanz. Editorial Castalia: Madrid; Martín Molina, Amílcar (2006): Agustín de Betancourt y Molina. Dykinson: Madrid; Bogoliúbov, Aleksei (1973): Un héroe español del progreso. Agustin de Betancourt. Seminarios y Ediciones: Madrid; Cioranescu, Alejandro (1965): Agustín de Betancourt. Su obra técnica y cientifica. Instituto de Estudios Canarios: La Laguna de Tenerife; Kuznetsov, Dmitry (2018): Betancourt. Ingeniero por excelencia. Ediciones Endymion: Madrid.

${ }^{22}$ http://fundacionorotava.es/. Betancourt. La Fundación Canaria Orotava de Historia de la Ciencia (FUNDORO) ha digitalizado la documentación relativa a la vida y a la obra del ilustre ingeniero Agustín de Betancourt. La página expone una biografía de Agustín de Betancourt según sus estancias en España, Francia, Inglaterra y Rusia. En primer lugar, se hace una descripción del contexto histórico. En segundo lugar, la evolución de la ciencia tanto en el siglo XviII como en el XIX, pues el biografiado vivió entre ambos periodos, y en tercer lugar, los manuscritos, publicaciones editadas, correspondencia, obra gráfica, maquetas y construcciones en las que intervino Agustín de Betancourt. Entre ellas se encuentra «Ensayo sobre la composición de máquinas», considerada la obra principal del científico, fue libro de texto durante muchos años en las Escuelas de Ingeniería de toda Europa. 
de Caminos, Canales y Puertos de Madrid, que lleva a cabo una importante labor de divulgación de la figura de Betancourt ${ }^{23}$. En Rusia existen diversas instituciones que se ocupan de estudiar la figura de Agustín de Betancourt, como la de la Universidad del Transporte de San Petersburgo y la Fundación de Nizhni Nóvgorod por la Popularización de la Vida y Actividad de A.A. Betancourt, creada en $1995^{24}$. Los españoles estamos aún en deuda con este científico universal; en cambio, en Rusia goza de un gran reconocimiento; sirvan como ejemplo las palabras pronunciadas por el expresidente Mijaíl Gorbachov en su primera visita a España en 1990 ya tantas veces citadas, y a las que volvemos a hacer referencia textualmente: "Llego a un país del que tengo inmejorables referencias. Vengo a una España en la que nació el más ilustre colaborador que jamás ha tenido Rusia: Agustín de Betancourt» ${ }^{25}$. Fue determinante esta mención de Mijaíl Gorbachov para redescubrir en España la figura y obra de Agustín de Betancourt. Otro ejemplo de que Betancourt sigue estando muy presente en San Petersburgo y el resto de Rusia ha sido la reciente construcción de un nuevo puente sobre el Neva que lleva su nombre a propuesta del actual rector de la Universidad Estatal de Vías de Comunicación de San Petersburgo, Alexander Panichev, con motivo de la celebración del Mundial de Fútbol 2018, celebrado en la ciudad de San Petersburgo ${ }^{26}$. Ya en 1978 la astrónoma rusa Lyudmila Zhuraclyova descubrió un asteroide entre Marte y Júpiter de 10 kilómetros de diámetro desde el Observatorio Astrofísico de Crimea; inicialmente se denominó 1978TO8 siguiendo la convención internacional. Su número de registro es el 11 446. Sin embargo, en 2003 la comunidad científica rusa realizó los trámites para que el asteroide 11446 pasase a denominarse «asteroide Betankur», para reconocer las aportaciones de Agustín de Betancourt al mundo de la ciencia y de la tecnología, que hizo que el Imperio ruso se situara al nivel de las primeras potencias euro-

${ }^{23}$ http://www.fundacionabetancourt.org/.

24 Cullen Salazar, Juan: op. cit., p. 63.

${ }_{25}$ Mijaíl Gorvachov, presidente de la URSS (1989-1991). Discurso oficial pronunciado en su primera visita a España el 26 de octubre de 1990. https://plus.google.com> posts.

${ }^{26}$ El 20 de noviembre de 1809 (el 2 de diciembre según el estilo nuevo) por el manifiesto del emperador Alejandro I fue fundado el Instituto del Cuerpo de Ingenieros de Caminos, la primera institución de enseñanza superior de transporte y construcción de Rusia, que actualmente lleva el nombre de la Universidad Estatal de Vías de Comunicación de San Petersburgo. El organizador y primer rector del Instituto del Cuerpo de Ingenieros de Caminos fue Agustín de Betancourt, uno de los científicos-mecánicos más importantes de su época. En el transcurso de la elaboración de los primeros planes de estudios y programas Agustín de Betancourt utilizó los mejores recursos en el sistema de la enseńanza técnica superior en Europa. En los primeros ańos del Instituto estudiaban los ingenieros de un amplio perfil de la construcción y los especialistas en el ámbito del transporte, pero ya en los años 30 del siglo XIX como consecuencia de la construcción en Rusia del primer ferrocarril (1837), en los programas del arte de la construcción fueron incluidas las secciones especiales dedicadas a la construcción y explotación de ferrocarriles. Véase Información de la Universidad Estatal de Vias de Comunicación de San Petersburgo. 
peas de principios del siglo XIX. Este asteroide sería el primer objeto de nuestro sistema solar en rendir tributo a un español ${ }^{27}$.

Dos son los temas que trataremos en este trabajo, uno relacionado con las personalidades del zar Alejandro I y de Agustín de Betancourt en el contexto histórico que les tocó vivir, y otro sobre la aportación de Agustín de Betancourt al urbanismo y a la arquitectura de San Petersburgo, la llamada Venecia del Norte. Con este trabajo se pretende rendir un sentido homenaje a Betancourt, nuestro compatriota más universal en el campo de la ingeniería, y reivindicar su figura en la transformación urbana de San Petersburgo en las primeras décadas del siglo XIX, y para que su obra no quede en el olvido recuperamos las palabras de Herodoto de Turios, el padre de la Historia, cuando exponía los resultados de sus búsquedas, y afirmaba lo siguiente: «Para que las cosas hechas por los hombres no se olviden con el tiempo y que las grandes y maravillosas acciones llevadas a cabo tanto por los griegos como por los bárbaros no pierdan su esplendor ${ }^{28}$, queremos que la obra de Agustín de Betancourt tanto en Espańa como en Europa y Rusia permanezca en el recuerdo del tiempo presente, porque el historiador está obligado a rendir cuentas del pasado.

\section{ENTRE LA ILUSTRACIÓN Y EL LIBERALISMO: EL ZAR ALEJANDRO I Y AGUSTÍN DE BETANCOURT}

Si la historia de Rusia tuviera un «Rey Sol como Luis XIV de Francia», ese sería el emperador Alejandro I, y si habría que citar al mejor ingeniero de la Europa del siglo XVIII y el primer cuarto del siglo xIX, sería sin duda Agustín de Betancourt. Y es por eso por lo que partimos de la siguiente pregunta. ¿Existe algún paralelismo entre la vida de Alejandro I y la de Agustín de Betancourt al margen de las grandes diferencias de sus biografías? Pese a todo, hemos observado que compartieron objetivos comunes para la modernizar San Petersburgo y el Imperio ruso. Así pues, aplicaremos el paradigma de la «Historia Comparada» para analizar aquellos principios que compartían y los que los diferenciaban, como la "capacidad de trabajo", la «carrera militar», la «educación», las «ideologías» y la «religiosidad», para finalizar con una aproximación al perfil psicológico de ambos personajes ${ }^{29}$.

27 Vicente Cabañas, Nadjejda (2009): La cuenta atrás. De la carrera espacial al turismo cósmico. Gobierno de Canarias: Las Palmas de Gran Canaria.

${ }^{28}$ BLOCH, Marc (1980): Introducción a la Historia. Fondo de Cultura Económica. FCE, Madrid, p. 51.

29 «La Historia Comparada es un "método histórico" que se ocupa de la reconstrucción de los procesos sociales y culturales diferenciables en cada grupo humano objeto de estudio». Véase Castro Alfín, Demetrio (1993): "Comprender comparando. Jalones de una búsqueda en historia y ciencias sociales». Studia histórica-Historia Contemporánea, vols. X-XI. Ediciones Universidad de Salamanca: Salamanca: 77-90; Rumeu de Armas, Antonio (1985): «El ilustrado Agustín de Betancourt: leve cala sobre su mentalidad». Anuario de Estudios Atlánticos. Madrid-Las Palmas, número 31, pp. 315-342. 
Tenían en común los ideales del despotismo ilustrado y el concepto de progreso de Jean-Jacques Rousseau. El emperador Alejandro I había nacido para gobernar y modernizar Rusia, y Agustín de Betancourt para mejorar a la humanidad a través de la ciencia y la razón; en ambos casos tuvieron que superar muchos escollos en sus respectivas vidas, pero se emplearon a fondo en las misiones encomendadas, pues los dos fueron unos trabajadores infatigables como se aprecia través de la correspondencia privada de Agustín de Betancourt, en la que existen tres notas manuscritas de Alejandro I escritas en francés a Betancourt, en las que expresa el mucho trabajo que tenía que hacer, y al mismo tiempo se puede percibir la relación de amistad que existía entre ambos. A continuación citamos dichas notas traducidas textualmente del francés:

1) Yo tengo esta tarde mucho que hacer, General, y no queriendo hacerte esperar te suplico que vengas mañana a las ocho. Todo tuyo, 25 de febrero de 1811.

2) Aún, todavía, General yo me veo obligado a posponer nuestro trabajo para mańana a la tarde por haber estado todo el día ocupado en despachar correos, te suplico que aceptes mis excusas. 26 de febrero de 1811.

3) En este momento General, en el que yo quería recibirte me acaba de llegar un correo con muchos despachos, cuya lectura me ha detenido hasta este momento. Con grande pesar me veo obligado a privarme del placer de recibirte esta noche por ser muy tarde y tener muchos negocios que despachar. Yo te suplico vengas aquí el sábado a la tarde. Todo tuyo 26 febrero $1812^{30}$.

En otra carta escrita por Betancourt a su hermano José en 1814, le confiesa que «el Emperador y todas las personas de la familia Imperial rusa me recibieron con unas distinciones que yo no podía ni pretender ni esperar. Desde luego me convidó el Emperador a comer con él todos los días que quisiera siendo muy pocos los que gozaban de este privilegio...." ${ }^{31}$.

En cuanto a la capacidad de trabajo de Agustín de Betancourt, se puede definir como extraordinaria; gestionó el tiempo con una exactitud matemática, en cierta ocasión le comentaba a su hermana Catalina que «no tenía tiempo ni para comer con sosiego ${ }^{32}$. Durante toda su vida mantuvo una actividad frenética respecto a todas las actividades que desarrolló tanto en Espańa como en Francia e Inglaterra, pero especialmente en Rusia, y gozó de una buena salud, como comentaba en una de sus cartas durante su estancia en París en 1789 en la que describía el

${ }^{30}$ Véase Cullen Salazar, Juan: op. cit., pp. 210-211.

31 AHBC. Leg. 9370. Carta n. ${ }^{\circ}$ 31. Agustín de Betancourt y Molina, desde San Petersburgo, a su hermano José Betancourt y Castro, en la Orotava, de fecha 15 de septiembre de 1814. Véase Cullen Salazar, Juan: op. cit., pp. 203-211.

32 Archivo Fernando J. del Hoyo Monteverde [AFJHM]. Carta n. ${ }^{\circ} 43$. Agustín de Betancourt y Molina, desde San Petersburgo, a Antonio Monteverde Rivas y esposa [su hermana "Catuja»], en La Orotava, de fecha 26 de diciembre de 1822. Esta es la última carta que escribió desde San Petersburgo Agustín de Betancourt, que fallecería el 14 de julio de 1824. Véase Cullen, Juan: op. cit., p. 267. 
frío extremo que hacía en el mes de enero, y hablaba de la «salud robusta que Dios me ha dado $»^{33}$. Además, realizó grandes viajes a lo largo de su vida, primero por España, después por Europa y por último en Rusia. Hay que destacar su último gran viaje en el interior de Rusia cuando tenía 62 años por orden del zar Alejandro I, para conocer de primera mano el estado de las vías de comunicación del Imperio ${ }^{34}$.

Inició este último largo viaje en agosto de 1820 desde Nizhni Novgorod, donde pasaba los veranos, para controlar las obras de la gran feria que se estaba construyendo y que se inauguraría en julio de 1822. A partir de aquí, descendió por el río Volga y visitó la ciudad de Kazán y siguió el río Kama, hasta el Caúcaso y Georgia, para dirigirse después al norte y visitar los puertos del mar Negro, Sebastopol, Feodosia, Odessa y Jerson; inspeccionó los ríos Dnieper, Seim y Oka, y en noviembre del mismo año regresó a San Petersburgo, para entregarle personalmente un informe al zar: «Rapport sur differents sujets relatifs aux voies de communication en Russie», en el que se recogía el estado lamentable de los caminos y el atraso de la sociedad rusa. Este informe molestó profundamente al zar, que desconocía la verdadera realidad del Imperio, silenciada por sus ministros y por los cortesanos aduladores como ocurrió en tiempos de su augusta abuela Catalina II, la ocultación de la realidad social a los zares autócratas se había convertido en una tradición. En este sentido existía una radical disparidad ideológica y ambiental entre la capital del Imperio y el resto del país, ya que en San Petersburgo se concentraban todas las energías del Imperio. Entre otras causas este informe fue el principio del fin de la amistad entre el zar y Agustín de Betancourt, porque fue malinterpretado, y sus enemigos en la corte aprovecharon esta circunstancia para desprestigiarle y acusarle de malversación de fondos de dinero público, hecho que se demostró falso; en definitiva el zar le retiró su apoyo. A partir de ahí, vivió los últimos años de su vida sumido en la más absoluta tristeza hasta su muerte en $1824 .{ }^{35}$ Agustín de Betancourt le sirvió al Zar «en todos [los] ramos» como él mismo expresaba en una carta dirigida a su hermano José en La Orotava en $1814^{36}$.

En principio tanto el zar como Betancourt compartieron la condición de militares, Alejandro I fue reconocido como un militar de gran valía, y ha destacado en la historia de Rusia y de Europa por sus victorias sobre Napoleón ${ }^{37}$. Después de la desastrosa retirada del ejército francés de Rusia en el invierno de 1812, los ejércitos rusos derrotaron a las tropas de Napoleón en Leipzig (1813) y Alejan-

${ }^{33}$ AHBC. Leg. 9325. Carta n. ${ }^{\circ}$ 9. Agustin de Betancourt y Molina, desde Paris, a sus padres, en La Orotava de 10 de enero de 1789. Véase Cullen, Juan: op. cit., p. 113.

${ }^{34}$ AHBC. Leg. 9370. Carta n. ${ }^{\circ} 31$. Agustin de Betancourty Molina, desde San Petersburgo, a su hermano José, en La Orotava, de fecha de 15 de septiembre de 1814. En esta carta explica los motivos que le llevaron a San Petersburgo: "Desde que observé la enemistad... Véase Cullen, Juan: op. cit., p. 258.

${ }_{35}$ Muñoz Alonso, Alejandro (2007): La Rusia de los zares. Espasa-Calpe: Madrid.

${ }^{36}$ AHBC. Leg. 9370. Carta n. ${ }^{\circ}$ 31. Agustin de Betancourty Molina, desde San Petersburgo, a su hermano José, en la Orotava, de fecha 15 de septiembre de 1814. Véase Cullen, Juan: op. cit., p. 207.

37 Alan Palmer, As (1974): Alexander I: Tsar of War and Peace. Weidenfelld and Nicholson: Londres 
dro I entró en París en la primavera de 1814; fue uno de los principales artífices de la destrucción del Imperio de Napoleón. Después de vencer a la "Grande Armeé», tomó parte en el Congreso de Viena en 1815 siendo el promotor de la Restauración en Europa y de la fundación de la Santa Alianza para imponer de nuevo el absolutismo en el continente europeo. A partir de entonces Alejandro I siguió una política autocrática y se apoyó en la Iglesia ortodoxa para luchar contra el liberalismo europeo en todas sus manifestaciones ${ }^{38}$.

En cuanto a Agustín de Betancourt, desde su primera juventud formó parte de la milicia, aunque nunca participó en guerras. En 1777, con diecinueve años, ingresó en el regimiento de infantería de La Orotava (Tenerife) en calidad de cadete, y ya en la Corte de Madrid ascendió a subteniente y teniente de armas; en 1792 alcanzó el grado de capitán en la Orden Militar de Santiago, que le serviría de plataforma para ascender en la escala social, y como distinción honorífica siempre llevó con orgullo bordada la cruz de Santiago en su uniforme militar. En diciembre de 1808 ingresó en el ejército ruso con el grado de mayor general para misiones especiales de su majestad imperial en el Departamento de Vías de Comunicación, análogo a la Inspección de Caminos y Canales español, obtuvo el grado de mariscal de campo, equivalente al que tenía en España, hasta llegar a ser nombrado en 1809 teniente general del Ejército ruso, y alcanzó el grado de ministro. En 1811 fue condecorado con la Orden de Alejandro Nevsky, una de las condecoraciones más importantes del Imperio ${ }^{39}$.

Debe resaltarse otro proyecto compartido entre estos dos personajes como el de potenciar la educación, considerada clave del progreso para acceder a una vida mejor. Alejandro I recibió una educación brillante, y su preceptor, el coronel suizo Fréderic-César Laharpe, le instruyó en las ideas del progreso de Jean-Jacques Rousseau y en los ideales del despotismo ilustrado, y en los conceptos nacionalistas que estaban de actualidad en la Europa del siglo XviII. Durante su reinado reformó el sistema educativo y fundó las universidades de Kazán y Karkow, además de reorganizar las de Dorpat y Wilna, y potenció la enseñanza en escuelas e institutos ${ }^{40}$.

Por su parte, Agustín de Betancourt como educador fue considerado un gran pedagogo y amaba enseñar respondiendo a las ideas ilustradas, a las liberales y al nuevo espíritu del capitalismo. A partir de 1791 pretendió que la Corona española fundara una Escuela de Caminos y Canales tomando como modelo l'École des Ponts et Chaussées de París, pero debido a los acontecimientos políticos ocurridos en España, y al descenso del impulso de la Ilustración durante el reinado de

38 Klimenko, Michael (2002): Tsar Alexander I: portrait of an autocrat. Hermitage Publishers: Tenafly.

39 AHBC. Leg. 9370. Carta n. ${ }^{\circ} 31$. Agustín de Betancourt desde San Petersburgo a su hermano José en La Orotava, de fecha 15 de septiembre de 1814, en Cullen, Juan: op. cit., pp. 203-211; Bethencourt y Castro; José (1842): Noticias biográficas de Don Agustín de Bethencourt y Molina escritas por su sobrino carnal Don José de Bethencourt y Castro de 1842. AHBC: La Orotava de Tenerife.

${ }^{40}$ Meuwly, Olivier (2011): Frédéric-César de La Harpe: 1754-1838. Bibliothèque historique vaudoise: Lausanne. 
Carlos IV y de su valido Manuel Godoy, tuvo que esperar a que la futura Escuela de Ingenieros fuera una realidad en $1802^{41}$. Precisamente elaboró un plan de estudios que duraría dos años, y en la misma fecha se imprimieron dos manuales para la formación de los alumnos: la Geometría descriptiva de Gaspar Monge y el Tratado de Mecánica de L.B. Francoeur ${ }^{42}$. Otra de las grandes aportaciones de Betancourt a la ciencia y a la técnica fue la inauguración en 1792 del Gabinete de Máquinas en Madrid, ubicado en el Palacio del Buen Retiro, cuya colección constaba de 270 modelos para el estudio de la hidráulica, 358 planos y 100 memorias manuscritas con 92 estampas, del que se sentía inmensamente orgulloso, como manifestaba en una carta desde París el 6 de marzo de 1789 a sus padre en la que exponía lo siguiente: «Tendré el gusto toda mi vida de haber formado el mejor Gabinete de máquinas que habrá en Europa». Todos estos materiales los reunió durante sus viajes por Francia e Inglaterra con una finalidad evidentemente didáctica ${ }^{43}$.

En relación con la enseñanza en San Petersburgo fundó en primer lugar la Dirección General de Vías de Comunicación, y desplegó todos sus conocimientos para establecer los planes de estudios del Cuerpo de Ingenieros, y finalmente el Instituto de Vías de Comunicación, que convirtió en la primera Escuela de Ingenieros Civiles de Caminos y Canales. Estaba ubicada en un edificio de estilo neoclásico propiedad del príncipe Yusupov, adquirido por el zar Alejandro I, y acondicionado por Agustín de Betancourt, con una finalidad académica. Después puso en marcha el Cuerpo de Ingenieros con la misma titulación y el Instituto o Colegio Militar para instruir a los ingenieros, del que fue director desde su nombramiento el 15 de septiembre de 1809 hasta su muerte en $1824^{44}$. En resumen, Betancourt lo organizó todo y fue profesor del Instituto, fijando sus bases gracias a la experiencia adquirida en la escuela de Caminos y Canales fundada anteriormente en Madrid en 1802, y en la Politécnica de París, en este sentido publicó un manifiesto fundacional del Instituto en el que se fijaba el número de alumnos, asignaturas, sistemas de exámenes y talleres ${ }^{45}$.

${ }^{41}$ Capel SÁez, Horacio et alii (1983): Los ingenieros militares en España, siglo XVIII. Repertorio bibliográfico e inventario de su labor cientifica y espacial. Universidad de Barcelona: Barcelona; SÁenz Ridruejo, Fernando (2005): Una historia de la Escuela de Caminos. Fundación Agustín de Betancourt. Escuela Técnica Superior de Ingenieros de Caminos Canales y Puertos y Ministerio de Fomento: Madrid. Sobre la España del siglo XviıI, véase García CárCel, Ricardo (coord.) (2002): Historia de España del siglo XVIII: La España de los Borbones. Cátedra: Madrid.

42 Prieto Pérez, José Luis (2003): "Agustín de Betancourt en su tiempo». Materiales de Historia de la Ciencia. Fundación Canaria Orotava de Historia de la Ciencia: La Orotava, Tenerife, pp. 19-42.

43 AHBC. Leg. 9327. Carta n. ${ }^{\circ}$ 11. Agustín de Betancourt, a sus padres en La Orotava de 6 de marzo de 1789, véase Cullen, Juan: op. cit., pp. 119-122. Sobre la recopilación de modelos del Real Gabinete de Máquinas, en Archivo Histórico Nacional [AHN]. Estado, Leg. 4088/9, Exp. 10; Bethencourt y Molina, José de: «Noticias biográficas de Don Agustín de Bethencourt y Molina...», op. cit., p. 57.

44 Prieto Pérez, José Luis: op. cit., p. 39.

45 Ibidem., p. 39. 
Agustín de Betancourt afirmaba que «en ninguna parte se enseñaba las matemáticas mejor que en mi establecimiento» ${ }^{46}$. En 1809 fue nombrado académico del Instituto de Francia en la clase de Ciencias, Física y Matemáticas. Siempre estuvo comprometido con la difusión de los saberes teóricos y prácticos. En 1813 fundó el Museo Central del Transporte Ferroviario de Rusia, donde había salas especiales para la disposición de objetos y se crearon talleres. Puso en marcha la Escuela de Ciencias Exactas, y reorganizó la Academia Imperial de Bellas Artes en San Petersburgo ${ }^{47}$. Además, en junio de 1819 fue nombrado por el zar miembro de la Sociedad Imperial de Mineralogía de Rusia ${ }^{48}$. Agustín de Betancourt combinó la pedagogía con su actividad como ingeniero, arquitecto, constructor e inventor. Tuvo una gran capacidad de investigación, de desarrollo e innovación; investigó en los campos más diversos de la ingeniería, desde el naval hasta las telecomunicaciones y la aeronáutica. Del mismo modo, realizó una extraordinaria labor como profesor y diseñador de planes de estudios de las Escuelas de Ingenieros de Caminos, Canales y Puertos de Madrid y de San Petersburgo, siguiendo el modelo de l'École des Ponts et Chausées de París ${ }^{49}$.

En lo referente a las ideologías hallamos similitudes y diferencias entre el zar y Betancourt. En el reinado de Alejandro I se pueden establecer dos fases bien diferenciadas desde el punto de vista de las ideas políticas; en la primera parte fue partidario de las reformas según el espíritu de la Ilustración e inspirado por el ejemplo de su abuela Catalina II; intentó llevar al país por el camino de la modernización del Estado y los progresos occidentales, y las reformas que deseaba emprender estaban próximas a la monarquía liberal, pero pocos de esos cambios llegaron a hacerse realidad. Era de temperamento autoritario y su formación intelectual acorde con los principios del Siglo de las Luces, que hicieron de Alejandro I un perfecto arquetipo de déspota ilustrado en el que se combinaron el absolutismo monárquico y la

46 AHBC, Leg. 9370. Carta n. ${ }^{\circ} 31$. Una de las cartas más interesante escrita a su hermano José en la Orotava, de fecha de 15 de septiembre de 1814. Véase Cullen, Juan: op. cit., p. 207; AHBC. Leg. 9406. Carta n. ${ }^{\circ}$ 41. Agustín de Betancourt y Molina, desde San Petersburgo, a su hermana María del Carmen, en La Orotava, de fecha 10 de octubre de 1821. Véase Cullen, Juan: op. cit., pp. 255-258. En esta carta Betancourt escribe lo siguiente a propósito de la enseñanza: «Como yo tengo mucha experiencia en la enseñanza de la juventud, no quiero dejar de darte mi parecer sobre lo que debes enseńar a nuestro sobrino. La lengua latina la miro como muy esencial en una buena educación, pero tanto aun más útil le serán las lenguas inglesa y francesa, y ahora (sino es un poco tarde) es cuando debe aprenderlas, y teniendo 15 o 16 (y no antes) se debe de aprender por un buen tratado de matemáticas, la aritmética, geometría y trigonometría y los principios de álgebra [...]. Unos buenos principios de física experimental le serán muy útiles y supongo que al mismo tiempo que los demás estudios le enseñarán la geografía y la historia»; Bogoliubov, Aleskei y García-Diego, José A.: 1986. "Agustín de Betancourt como pedagogo». Revista de Obras Públicas. Madrid, pp. 703-718.

47 Padrón Acosta, Sebastián: op. cit., p. 45.

48 Carta del zar Alejandro I sobre el nombramiento de Agustín de Betancourt. Véase http:// fundacionorotava.es/.

${ }^{49} \mathrm{http}: / /$ fundacionorotava.es/. biography. http://fundacionorotava.es/betancourt/biography/13/. 
ideología progresista. Él mismo se definía con esta frase ante su ministro de Justicia Gavrila Derzhavin: «iYo soy un emperador autócrata y lo seré, nada más! ${ }^{50}$.

En la segunda parte de su reinado después de la derrota de Napoleón, llevó a cabo una política conservadora y reaccionaria, convirtiéndose en el árbitro de Europa después del Congreso de Viena en 1815 con la fundación de la Santa Alianza para la defensa del régimen absolutista y luchar contra el liberalismo. Hacia 1820 reaccionó frente a los movimientos revolucionarios que agrupaban a las clases progresistas, sobre todo a grupos de oficiales jóvenes en contacto con el liberalismo europeo. Alejandro I cambió su política y tomó una serie de medidas autoritarias como, por ejemplo, restablecer la censura y prohibir las asociaciones políticas. Los últimos años de su vida y reinado se caracterizaron por un talante reaccionario y despótico. Pasó de un cierto liberalismo a un absolutismo feroz. En definitiva, sus propuestas de cambio fueron más teóricas que prácticas ${ }^{51}$. Los historiadores llamaron a su reinado «el de las esperanzas frustradas», porque el pueblo de Rusia y el ala progresista de la nobleza esperaban reformas radicales que nunca llegaron a realizarse por la corrupción imperante en la administración imperial, y por el carácter indeciso del $\operatorname{zar}^{52}$.

En cambio, Agustín de Betancourt se formó en las ideas ilustradas dentro del seno familiar, una familia ilustrada, que pertenecían a la élite de la isla de Tenerife, y recibió una esmerada educación. Siempre manifestó deseos de saber, su primera formación la recibió en su tierra natal; aprendió latín, su lengua preferida, y le enseñó francés su madre, fue un consumado políglota, pues además del español hablaba también inglés y alemán, y aprendió ruso ${ }^{53}$. Con 20 años se trasladó a Madrid, donde se formó en el Real Colegio de San Isidro, y en la Real Escuela de Bellas Artes de San Fernando, a partir de 1779 amplió estudios en París y en Inglaterra (1793-1795), y entre (1791-1807) desarrolló una gran labor en España ${ }^{54}$.

Le influyeron las ideas progresistas de la Revolución Francesa, pero después del periodo del Terror, volvió a posturas más conservadoras, aunque siempre admiró el liberalismo inglés; en la última etapa de su vida se le puede situar dentro de un liberalismo moderado, aunque no intervino en política su ideología le perju-

${ }^{50}$ Evreinov, Ludmila (2002): Alexander I, Emperor of Russia: a reappraisal. Xlibris Corp: Nueva York

51 Troyat, Henri (2002): Alexander of Russia: Napoleon's conqueror. Grove Press: Nueva York; http://rusopedia.rt.com/. issue-269.

${ }^{52}$ McConell, Allen (1970): Tsar Alexander I Paternalistic Reformer. A.H.M. Publishing Corporation: Arlington Heights.

53 AHBC. Leg. 9406. Carta n. ${ }^{\circ}$ 41. Agustín de Betancourt, desde San Petersburgo, a su hermana María del Carmen, en La Orotava, de fecha 10 de octubre de 1821. Véase Cullen, Juan: op. cit., pp. 255-258. Betancourt en esta carta expone la utilidad de la lengua inglesa y francesa, aunque el latín según él es fundamental en una buena educación.

54 Rodríguez Mesa, Manuel (1996): El entorno familiar de Agustín de Betancourt. Ministerio de Obras Públicas, Transporte y Medio Ambiente. CEHOPU: Madrid; GouzÉvitch, Irina (2010): «Les voyages en France et en Anglaterre et la naissance d'un expert technique: le cas d'Augustin Betancourt (1758-1824)». Documents pour l'histoire des techniques, 19, pp. 97-117. 
dicó primero en España, de donde tuvo que exiliarse, como explica en una carta a su protector el conde de Floridablanca, ministro de Carlos III y Carlos IV:

No queriendo admitir las ofertas que se me hicieron de parte del emperador Napoleón y de su hermano Joseph, me vine aquí [a San Petersburgo], donde este emperador me ha acogido del modo más honorífico... Nada deseo con más ansia sino que se compongan las cosas del modo que nuestra patria pueda recobrar su legítimo soberano; entonces no habrá recompensas ni promesas que me impidan ir a servirle el resto de mis días...55.

También informó a su familia canaria de los motivos que le llevaron a exiliarse, como se recoge en otra carta del 15 de septiembre de 1814 desde San Petersburgo:

Desde que observé la enemistad que reinaba en España entre el príncipe de Asturias (hoy Fernando VII) y Godoy, supuse que debía haber una revolución en España y que en tal caso era necesario, para no perecer con mi familia, buscar un asilo en un reyno extranjero en que ponerla a salvo, y me pareció que Rusia debía ser el mas apropósito...56.

Si bien es verdad que los acontecimientos históricos de una etapa convulsa como fue la crisis política española de los primeros años del siglo xIx, y la invasión de Napoleón a España, que desencadenó la guerra de la Independencia de 1808, le obligaron a optar por el exilio; en aquellas fechas Betancourt se hallaba en París, y solamente tenía dos opciones: una, ponerse al servicio del rey intruso en España José I Bonaparte, hermano de Napoleón, o ser encarcelado en la fortaleza de Vicennes. En 1807 había estado en Alemania y con motivo de la conferencia de Erfurt estableció relaciones con el zar Alejandro I para buscar una alternativa a su complicada situación personal, y le ofreció sus servicios. El zar ya había sido informado de la extraordinaria valía de Betancourt, y le ofreció un sueldo notable para que coordinara la enseñanza de la ingeniería en Rusia, porque el principal objetivo del zar era modernizar el Imperio. Después del encuentro en Erfurt, Betancourt se trasladó a San Petersburgo, donde adquirió con el zar Alejandro I el compromiso de trabajar en el ámbito de la investigación y la invención en la ingeniería. Ese mismo año regresó a París para trasladarse definitivamente con su familia a San Petersburgo en $1808^{57}$.

Sin embargo, su ideología liberal y el apoyo de Betancourt a la revolución liberal de España en 1820, que fue la causa por la cual Rusia y Francia declararan la guerra a España en 1823 mediante la invasión de los «Cien Mil Hijos de San

55 Besora i Forx, Roger (2014): «Agustín Agustinovich Betancourt, Ministro del Zar». A la luz de San Petersburgo. Fundación Esteyco: Madrid, p. 93.

56 AHBC. Leg. 9370. Carta n. ${ }^{\circ}$ 31. Agustin de Betancourty Molina, desde San Petersburgo, a su hermano José, en La Orotava, de fecha 15 de septiembre de 1814. Véase Cullen, Juan: op. cit., p. 206.

57 Rumeu de Armas, Antonio (1987): Agustín de Betancourt (1758-1824). Fundación Juan March: Madrid, p. 5. 
Luis», que restablecieron el régimen absolutista del rey Fernando VII, fue otro de los motivos por los que el zar le retiró definitivamente su favor, y en la última entrevista que mantuvieron el 22 de enero de 1822 le despidió con esta frase lapidaria: «No le culpo a usted, sino a mí mismo, de haberle asignado un puesto para el que no estaba dotado y al cual usted renuncia ${ }^{58}$. Esta fue la mayor humillación que sufrió Betancourt, el desprecio y la ingratitud del zar como recompensa a todos los grandes servicios prestados al Imperio, como suele ocurrirles a bastantes grandes hombres al final de su carrera ${ }^{59}$. Pese a todo, cuando se acercaba el final de su vida tras «una enfermedad aguda consecuencia de sus largos y penosos trabajos», el zar Alejandro I le escribió una carta autógrafa para expresarle su simpatía y tranquilizarle con respecto al futuro de su familia, porque esta era una de las grandes preocupaciones de Betancourt ${ }^{60}$. Cuando murió, el zar Alejandro I mandó organizar el entierro y ordenó que se le rindieran honores militares. Con este motivo, al duque de Würtemberg, que le había sustituido en los cargos, menos en el de «director general de Puentes y Calzadas», que mantuvo hasta su muerte, y que además le había humillado públicamente, pues tenía un carácter violento, no le quedó más remedio que cumplir las órdenes del zar y difundir el siguiente comunicado:

El Cuerpo de las vías de comunicación ha perdido con el Sr. De Betancourt un general distinguido, tanto por sus vastos y profundos conocimientos, como por los raros méritos que lo hacían tan útil en los diferentes ramos de la especialidad. Esta pérdida será sentida hondamente por todos los oficiales del cuerpo, y muy particularmente por los que se han formado bajo su dirección en la Escuela de Ingenieros ${ }^{61}$.

Asimismo, el zar ordenó que se le asignara una pensión a su esposa Ana Jourdain. En realidad, Agustín de Betancourt nunca formó parte de los cortesanos aduladores, porque se consideró siempre un hombre independiente.

Por otro lado, Agustín de Betancourt desde sus posiciones liberales apoyó a otros miliares españoles acogidos en el Ejército ruso, y sobre todo le perjudicó su ayuda al militar y aventurero español Juan Van Halen, que llegó a San Petersburgo en 1818, y que asistía a las reuniones secretas de la «Unión de Salvación» y a la logia masónica "Asturias", a la que también acudían otros españoles, entre ellos Bauzá, Viana y Espejo, ayudantes de Betancourt, este último era un "afrancesado» y se casó con la hija mayor de Betancourt ${ }^{62}$. Esta logia agrupaba a aristócratas y ofi-

58 Besora i Foix, Roger: op. cit., p. 127.

59 Fernández González, José, Cabrera González, Abelardo y Curbelo Cruz, José Antonio (2006): Agustín de Betancourt en la Historia de la Ciencia. IES Agustín de Betancourt: Puerto de la Cruz, p. 72.

${ }^{60}$ Cioranescu, Alejandro: op. cit., p.34.

${ }^{61}$ Ibidem., p. 35.

${ }^{62}$ Joaquín Espejo era un ingeniero español contratado por Agustín de Betancourt en 1818 para trabajar en Rusia. Tuvo que exiliarse de Espańa por ser afrancesado, y se casó con la hija mayor de Agustín de Betancourt, llamada Carolina, que falleció en 1822 al dar a luz. Este hecho luctuoso significó un gran golpe para su padre, y de alguna forma aceleró su final muriendo dos años des- 
ciales comprometidos en la preparación de un movimiento liberal. En 1820 Juan Van Halen fue expulsado de Rusia al ser informado el zar de su intención de reintegrarse al Ejército español, una vez triunfante el levantamiento del general Rafael del Riego en la localidad de Cabezas de San Juan, en la provincia de Sevilla, para restablecer la Constitución española de $1812^{63}$.

Visto desde cierta distancia Agustín de Betancourt fue prudente en sus manifestaciones políticas, sabemos de su proximidad a los círculos revolucionarios franceses moderados, era lector de Voltaire y Rousseau, partidario del progreso, de la razón, y de espíritu abierto, motivos todos ellos que le empujaron al exilio profesional de España ${ }^{64}$.

En lo tocante a la «religiosidad» se movieron en diferentes planos, de ahí que a Alejandro I haya que situarle en un contexto de conservadurismo religioso, mientras que Agustín de Betancourt vivió una religiosidad ilustrada. En primer lugar al zar se le consideraba un monarca por derecho divino con poder ilimitado, y representante de Dios en la tierra desde los tiempos de Iván IV el Terrible. Se crio en la tradición religiosa y en las ideas de la Ilustración. Era de naturaleza muy creyente; después de la victoria sobre Napoleón orientó su política de acuerdo con los principios religiosos de la viuda Krüdener, y en ese contexto prestó apoyo a las Sociedades Bíblicas, que preconizaban la unidad de todos los cristianos, hay que señalar una etapa de acercamiento al papa de Roma. Llegó a tal extremo su «religiosidad» que bien se podría calificar como "patológica», pues en 1817 rebautizó el Ministerio de Educación como «Ministerio de Asuntos Espirituales y Educación Popular» para encauzar la «moralidad» de la cultura rusa, que supuso también un giro conservador en la política estableciéndose una alianza entre "el trono y el altar», y los vínculos entre el Estado y la Iglesia se fortalecieron a lo largo del siglo XIX $^{65}$. Fue un zar abiertamente confesional, así en un manifiesto de postguerra en 1816 afirmaba que Napoleón era un tirano, cuyo acceso al trono imperial fue «motivado por la pasión de un pueblo que abandonó a su Dios» y más tarde fue derrotado por «venganza divina ${ }^{66}$.

No es de extrañar que uno de los objetivos de Alejandro I, después de la caída del Imperio de Napoleón, fuera la fundación de la Santa Alianza en el Congreso de Viena de 1815, con el fin de reorganizar Europa e implantar el cristianismo en las potencias europeas, en este sentido se impuso el «mesianismo ruso» pero fue

pués en 1724. Véase AHBC, Leg. 9542. Carta n. ${ }^{\circ}$ 38. Agustin de Betancourt y Molina, desde San Petersburgo, a su hermana María del Carmen, en La Orotava, de fecha de 10 de junio de 1820. Véase Cullen, Juan: op.cit., p. 243; Artola, Miguel (2008): Los afrancesados. Alianza Editorial: Madrid. 63 https://es.wikipedia.org/wiki/Juan_Van_Halen_y_Sart\%C3\%AD. Sobre Juan VanHalem véase la novela de Baroja, Pío (1998): Juan Van-Halen, el oficial aventurero. Edición de Juan Van-Halen. Biblioteca Edaf: Madrid, pp. 223-298.

${ }_{64}$ Prieto Pérez, José Luis: op. cit., p. 33.

65 Almedingen, Edith Martha (1964): The Emperor Alexander I. Bodley: Londres; Matos Franco, Rainer María (2017): Historia minima de Rusia. El Colegio de México: Editorial Tarner: Ciudad de México, México, s.p. (Versión electrónica).

${ }^{66}$ Matos Franco, Rainer María: op. cit., s.p. 
un fracaso a corto plazo. En el Congreso de Viena Alejandro I se convirtió en árbitro de la nueva Europa y fue una de las personalidades más fuertes ${ }^{67}$. En la última etapa de su vida cayó en el misticismo, y vivió con un sentimiento de culpa por el asesinato de su padre el zar Pablo I, y un profundo arrepentimiento le acompañará el resto de su vida. Esa búsqueda de paz y perdón le llevó por diferentes caminos religiosos hasta el punto de que el visionario lionés Bergasse lo convirtió al protestantismo metodista. Sin embargo, apoyó a la Iglesia ortodoxa, el mejor sostén religioso de la monarquía absoluta. Él mismo se consideraba el salvador de la humanidad después de la derrota de Napoleón, y pensaba que había cumplido con una misión divina. El tema religioso fue otra de las contradicciones que caracterizaron su vida y perduraron después de su muerte ${ }^{68}$.

En efecto, Agustín de Betancourt poseía una reconocida religiosidad y una moralidad profunda, junto con una fe razonable acorde con la filosofía y la ciencia contemporánea. Había nacido en una familia de profundos principios religiosos. Betancourt practicaba la moderación religiosa dentro de las ideas de la Ilustración, que unían la razón y la revelación con el fin de renovar los conceptos de fe y piedad ${ }^{69}$. Siempre estaba dispuesto a aceptar la voluntad de Dios con paciencia como se desprende de sus cartas, y en una de ellas, escrita desde París el 10 de enero de 1789 da gracias a Dios por lo estimado que era, y así se expresaba: «Yo creía que sólo los aduladores tenían partido en la Corte, pero veo que vale más hablar claro y obrar bien [...] cuando he creído tener razón para ello y no he tenido miedo de que me echen nada en cara $»^{70}$. Manifestaba una profunda resignación cristiana, como se aprecia en otra carta escrita a su hermana Catalina desde San Petersburgo el 1 de octubre de 1819 en la que decía: «Corramos un velo sobre las desgracias pasadas y demos gracias al que así lo ha dispuesto para ejercitar nuestra paciencia y resignación con su Santa Voluntad $»^{71}$. Se le puede definir como un buen cristiano.

Por último, nos aproximaremos al perfil psicológico del zar Alejandro I y de Agustín de Betancourt según los testimonios de la época. Primeramente nos centraremos en el zar, que era físicamente bien parecido, se le podría definir como un hombre guapo según los cánones de belleza de la época, alto, rubio, de ojos azules, Barcelona.

${ }^{67}$ González Ruiz, Nicolás (1951: Dos emperadores: Napoleón, Alejandro I. Cervantes:

68 Sementovwski-Kurilo, Nikolai (1941): Alejandro I, euforia y recogimiento de un alma. Espasa-Calpe: Madrid; Burleigh, Michael (2013): El poder terrenal. Religión y politica en Europa. De la Revolución Francesa a la Primera Guerra Mundial. Taurus: Barcelona.

${ }_{69}$ Payne, Stanley G. (2006): El catolicismo español. Editorial Planeta: Barcelona.

${ }^{70}$ AHBC. Leg. 9321. Carta n. ${ }^{\circ}$ 5. José de Betancourt-Castro y Molina, desde Madrid, a sus padres y hermana Maria del Carmen, en la Orotava, de fecha 25 de septiembre de 1788. Véase Cullen, Juan: op. cit., pp. 87-90.

${ }^{71}$ AHBC. Leg. 9540. Carta n. ${ }^{\circ}$ 37. Agustin de Betancourt y Molina, desde San Petersburgo, a su hermana Catalina, en La Orotava, de fecha de 1 de octubre de 1819. Sobre «las desgracias pasadas» se refiere a la muerte de su hermano José el 26 de abril de 1816 al que estaba muy unido, y de su sobrino Agustín hijo de su hermano José en diciembre del mismo año. Véase Cullen, Juan: $o p$. cit., pp. 235-239. 
de aspecto respetable, inteligente, bondadoso, valiente, austero, sencillo, de trato fácil y franca conversación, también le describen de carácter complicado ${ }^{72}$. Pero al mismo tiempo fue poco decidido en los asuntos de Estado. Tuvo una vida familiar complicada, se movió entre el amor de su abuela Catalina II, era su nieto predilecto, y el odio a su padre el zar Pablo I, la muerte de este pudo ser la causa de su «tristeza» llamada el «mal del siglo», esto hizo que le apodaran "el Hamlet del Norte», los remordimientos le acompañaron toda la vida después del asesinato de su padre al formar parte él mismo de la conjura que pretendía destituirlo. Lo mismo que el héroe de Shakespeare siempre dio muestras de una gran indecisión ${ }^{73}$. Por otro lado, su matrimonio con la princesa Luisa María Augusta de Baden fue bastante dramático, y sobre todo la muerte de su adorada hija María Narýshkina, nacida de la relación con una de sus amantes, su pérdida significó una verdadera tragedia para Alejandro $\mathrm{I}^{74}$.

Estaba considerado como una figura destacada, muy hábil en el juego político y diplomático, inspiraba gran admiración a quienes estaban cerca de él. Contemporáneos de Napoleón y del príncipe Metternich le describieron como una persona de carácter ambiguo y bipolar, y le dedicaron palabras poco halagadoras. Napoleón le definió como "un bizantino sospechoso", sin embargo este calificativo hay que tomarlo con cautela. La figura de Alejandro I en la historia rusa resulta ambivalente y obtuvo muchas críticas en vida y después de su muerte ${ }^{75}$.

Como colorario, los últimos años de su vida fueron de desencanto, en cierto modo abandonó sus ideales de servicio al pueblo ruso. Después de su muerte a los 48 años en un viaje a Taganrog a orillas del mar de Azov entró en la leyenda por los numerosos rumores indemostrables de que en realidad no había muerto, sino que se había retirado a un monasterio a terminar sus días meditando ${ }^{76}$. En Alejandro I confluían una serie de contradicciones que marcarían los vaivenes de su vida personal y de su reinado. Se definió a sí mismo como «el libertador de Europa» y se creía «el elegido de Dios para restaurar las monarquías absolutas» $»^{77}$.

Para conocer el perfil psicológico de Agustín de Betancourt resulta de gran utilidad su correspondencia familiar y la imagen que proyectaba en los retratos que se conservan de él, que le representan con unos rasgos bien proporcionados, destacan sus ojos de un azul intenso que traslucen inteligencia, bondad, y una cierta tristeza por el desarraigo que vivió a lo largo de su vida, y sus gestos desprenden algo

72 AHBC. Leg. 9369. Carta n. ${ }^{\circ}$ 30. José y María del Carmen de Betancourt y Molina, desde La Orotava a su hijo y sobrino Agustín, en Inglaterra, de fecha 21 de mayo de 1814. Alejandro I después del Tratado de París en 1814, una vez que abdicó Napoleón, se dirigió desde Francia a Londres y fue recibido por el futuro Jorge IV, por incapacidad de su padre Jorge III, y gozó de gran popularidad por su «fácil trato y franca conversación». Véase Cullen, Juan: op. cit., pp. 197-201.

73 https://historia-biografia.com/. biografi...

74 rusopedia.rt.com. políticos, issue_269.

75 Mourousy, Paul (1999): Alexander Ier, tsar de Russie: un sphinx en Europe. Rocher. Mònca.

76 Miguens, Silvia (2011): Alejandro Romanov. La leyenda del zar melancólico. Madrid: Ediciones Nowtilus.

77 http://www.mcnbiografias.com/app-bio/. shoaw. 
de melancolía. Sus retratos ofrecen una imagen contenida. Fue una persona de profundas convicciones, de excelentes principios, y gozaba de una extraordinaria inteligencia. Estaba adornado de grandes valores, entre ellos hay que destacar el amor a los demás, la amistad, la libertad, la tolerancia, practicaba la «ética del cuidado» con su familia, amigos y subalternos, fue una persona generosa, y sirva de ejemplo este testimonio en el que renuncia a la herencia familiar en favor de sus hermanas: «Hallándome por la misericordia de Dios en una situación de no necesitar de nada me servirá de la mayor satisfacción que lo poco o mucho que pueda tocarme de la herencia por parte de padre, madre o primo Valois lo repartan tú y Mariquita dándole a ésta dos partes y una a ti $\gg^{78}$.

Por lo demás era honrado, justo, sobrio, sencillo, pundonoroso, coherente con sus ideas, y jamás renunció a los principios ilustrados, era un ingeniero polifacético y apasionado de la ciencia, poseía una sabiduría enciclopédica. Sabía manifestar el cariño a quienes estaban a su alrededor, y profesaba una fidelidad sin condiciones a aquellos que formaron parte de su existencia. Y, por supuesto, fue un hombre de acción, y un alma sensible, mantuvo siempre una gran dignidad. Era una persona de categoría, y no fue ambicioso en lo material, poseía gran entereza de ánimo, y se consideraba una persona feliz como manifestaba en una carta a su hermana Catalina en octubre de 1819 en cuyo texto decía lo siguiente: «Vivo feliz alegrándome cada vez de haber tomado el partido de venir a servir a éste magnánimo Soberano, quien me distingue de un modo, que no me deja nada que apetecer ${ }^{79}$.

En Rusia Agustín de Betancourt es considerado un «héroe nacional», en España para la mayoría «casi un desconocido».

\section{LA APORTACIÓN DE AGUSTÍN DE BETANCOURT A LA ARQUITECTURA Y AL URBANISMO DE SAN PETERSBURGO}

En lo referente a los resultados de la transformación urbana de San Petersburgo, en las primeras décadas del siglo xIx fueron asombrosos, y una parte importante se debe a las obras realizadas por Agustín de Betancourt, que puso en práctica las técnicas y la experiencia adquirida en Madrid, París y Londres al servicio de Alejandro I. Toda la presión urbana en las primeras décadas del siglo XIX se focalizó en los terrenos contiguos al barrio del Almirantazgo hacia el sur de la ciudad, en la tierra firme. A principios del siglo xIx la isla Vasilievski dejó de ser el centro de la ciudad, y en los primeros decenios de este siglo se iría completando el desarro-

${ }^{78}$ AHBC, Leg. 9540. Carta n. ${ }^{\circ}$ 37. Agustin de Betancourty Molina, desde San Petersburgo, a su hermana Catalina, en la Orotava, de fecha 1 de octubre de 1819. Véase Cullen, Juan: op. cit., pp. 235-239.

79 Cullen, Juan: op. cit., p. 238. 
llo de la ciudad noble impulsada por el zar; al mismo tiempo se desarrollaron grandes proyectos por la extensa geografía rusa ${ }^{80}$.

Después de la derrota de Napoleón en 1812 se realizaron una serie de monumentos conmemorativos y numerosas obras públicas en San Petersburgo y Moscú, que había quedado arrasado después de la ocupación francesa. En 1816 se fundó el "Comité para las Construcciones y Obras Hidráulicas», y Betancourt estuvo al frente de este Comité por orden del zar, con el fin de ocuparse del urbanismo y del ornato de la ciudad. Se encargó de todos los proyectos y obras, así como de la totalidad de los planos del urbanismo. Se ocupó de la higiene urbana, de dragar los canales, canalizar las aguas de lluvia, mejoró el trazado y el pavimento de las calles, se tomaron medidas contra el fuego, se urbanizaron los suburbios, se construyeron puentes y se trazaron nuevos canales, y la construcción de la primera carretera importante de San Petersburgo-Novgorod-Moscú, y las conexiones de la capital con Narva y con la frontera de Finlandia ${ }^{81}$.

Naturalmente, los trabajos para embellecer la ciudad se continuaron hasta mediados del siglo xx. Puede afirmarse sin exageración que el aspecto clásico de San Petersburgo que se configuró durante los años de 1810 a 1830 es en gran parte heredero del esfuerzo continuado del "Comité Hidráulico» que Betancourt supo dirigir, y guiar los trabajos de los arquitectos y de los ingenieros ${ }^{82}$. En 1818 fue nombrado «director general de Vías de Comunicación», que actualmente equivale al cargo de ministro de Obras Públicas o de Fomento, y bajo sus órdenes estaban arquitectos de renombre como Karl Rossi, Vassilij Stassov, Andrei Mikhailov, Antoine-François Mauduit y tres ingenieros: Guillaume Traitteur, Aleksandr Gotman y Pierre-Dominique Bazaine. Todas las obras de la ciudad estaban sometidas a este «Comité Hidráulico» encargado de todos los proyectos ${ }^{83}$.

El primer proyecto que realizó Betancourt en San Petersburgo consistió en la construcción de un acueducto de 15 kilómetros de longitud, que traía agua potable desde Taitsi hasta el palacio imperial de Catalina en Tsárkoye Seló, a las afueras de San Petersburgo, en cuyo parque está la famosa fuente con la escultura de «La lechera de la cántara rota», que le inspiró al poeta Pushkin los siguientes versos:

Sobre la roca deja caer una jarra de agua la joven.

Tristes sus ojos mirando el trozo inútil.

Magia: el agua que fluye del ánfora no se acaba.

Desconsolada la joven mira el chorro que nunca se agota.

Aleksandr Pushkin ${ }^{84}$.

${ }^{80}$ Besora i Forx, Roger et alii. (2014): A la luz de San Petersburgo. Madrid. Fundación Esteyco, p. 102.

${ }^{81}$ https://es.rbth.com/. cultura, 80786-san...

82 http://fundacionorotava.es/.

83 GouzÉvitch, Irina: «Les voyages en France et en Anglaterre et la naissance d'un expert technique: le cas d'Agustín Betancourt (1758-1824)». Documents pour l'histoire des techniques, 19, 2010, pp. 97-117. http://journals.openedition.org/dht/1511.

${ }^{84}$ Besora I FoIX, Roger: op. cit., p. 112; Dmitry Kuznetsov, op. cit., pp. 225-227. 
Asimismo, se construyeron los edificios de la plaza del Senado, los palacios Elaguin, Mijalovski y sus zonas adyacentes, se reconstruyeron las caballerizas del Moika, y en 1818 se comenzó la construcción de la catedral de San Isaac, las obras finalizaron en $1858^{85}$. Previamente existió una pequeńa iglesia de madera mandada construir por Pedro el Grande y dedicada a san Isaac de Dalmacia, a la que sustituyó otra de piedra que a mediados del XVIII quedó inservible, y a principios del XIX se decidió edificar la nueva iglesia ${ }^{86}$.

Sin embargo, sería el relojero francés Abrahán Breguet, socio y amigo de Betancourt, quien le recomendó a Auguste Montferrand, también francés, que con apenas experiencia profesional pero muy hábil con el dibujo, comenzó a trabajar como delineante en el Comité de Construcciones, y animado por Betancourt presentó un proyecto de reconstrucción de la catedral de San Isaac que sería aprobado por el zar, nombrándole ingeniero imperial, aunque sería Betancourt quien supervisara las obras, y como relataba Auguste de Montferrand en una carta escrita el 11 de agosto de 1852, y dirigida al hijo de Betancourt, Alfonso de Betancourt y Jourdain, en la que afirmaba que él era el "maçon [albañil] de su padre»" ${ }^{87}$.

Antes de comenzar en 1818 la construcción, se demolió la iglesia anterior y se consolidó el suelo, ya que el terreno era muy pantanoso. La operación de cimentación de la catedral de San Isaac la diseñó Betancourt, esta fue larga y compleja; reforzó los cimientos, y la catedral se edificó sobre 24000 pilotes de pino alquitranado de 25 centímetros de diámetro cada uno, y se colocaron losas de granito cubiertas de piedra caliza sobre los pilotes. La cimentación tiene un grosor de 14,5 metros, 7,5 metros de altura de los pilotes y otros 7 metros de espesor de las losas de piedra. Betancourt siempre buscaba la solidez y la firmeza de las edificaciones. En el interior de la catedral se expone una maqueta del artificio concebido por Betancourt para elevar las columnas de granito rojo del exterior traídas desde las canteras de Finlandia y las columnas del interior del templo, que fueron recubiertas de malaquita y lapislázulii ${ }^{88}$.

En 1819 Betancourt aprobó el diseño del arquitecto Karl Rossi para urbanizar la plaza de Invierno, que era el corazón aristocrático y político de la ciudad, donde estaban los órganos de gobierno y el palacio principal del zar. Tenía que convertirse en un espacio público grandioso, y se decidió colocar en el centro de la plaza la columna de Alejandro I, obra de Montferrand, elevada sobre un pedestal, y coronada por un ángel de un notable parecido a la fisonomía de Alejandro I, fue diseñada por Montferrand, inspirándose en la columna de Trajano de Roma, y está apoyada sobre la base de 1500 pilotes de pino de seis metros de alto, y alcanza una altura de 47,5 metros, es de granito rojo de las canteras de Finlandia. Se utilizó el método inventado por Betancourt para asentar los cimientos, y los andamios que

\footnotetext{
${ }^{85}$ http://fundacionorotava.es/.

86 https://es.wikipedia.org/wiki/Catedral_de_San_Isaac.

87 http://fundacionorotava.es/.

${ }_{88}$ Historic Centre of Saint Petersburg and Related Groups of Monuments. UNESCO
} Culture Sector. 
había diseñado para elevar las columnas de la catedral de San Isaac años antes. La construcción duró de 1829 a 1834, y se inauguró diez ańos después de la muerte de Betancourt $^{89}$. La columna del zar Alejandro I constituye un homenaje a la victoria militar del zar sobre Napoleón.

Por su parte Betancourt proyectó en San Petersburgo en 1816 la nueva fábrica de papel moneda, llamada de Goznak, y de otros papeles de banco a orillas del río Fontanka muy cerca del puente egipcio, cuya construcción finalizó en 1818. El conjunto constaba de grandes volúmenes, sencillos y compactos con fachadas neoclásicas muy espartanas. En Rusia los primeros rublos de papel se emitieron en 1769 durante el reinado de Catalina II, entonces la emisión de papel moneda no estaba cubierta por las reservas del banco, y a principios del siglo xIx Rusia estaba inundada de billetes falsos fabricados dentro y fuera del país, antes de la guerra con Napoleón se imprimían en Francia, y con motivo de la invasión se diseminaron por toda Rusia. En 1816 se decidió cambiar el papel moneda con el objetivo de combatir las falsificaciones de dinero impresas por los franceses durante la ocupación en 1812, que suponía una amenaza de crisis económico-financiera para el país. Durante dos años Betancourt dirigirá y controlará las obras, y de hecho se encargó de los distintos departamentos: de la imprenta, del diseño de las máquinas de vapor, y del utillaje, que se fabricaron una parte en San Petersburgo, y otra en Inglaterra. También proyectó la maquinaria y dibujó el nuevo diseño de los billetes, que se imprimieron en un papel de mayor calidad para evitar falsificaciones masivas ${ }^{90}$. Él mismo se ocupó del diseño artístico de los billetes, que hasta entonces eran de tan baja calidad que el rublo se había hundido. Finalmente entre 1818 y 1820 se imprimieron los primeros rublos de calidad, y se procedió al cambio total de los billetes en circulación en toda Rusia por los nuevos. Actualmente esta fábrica de papel moneda sigue en funcionamiento ${ }^{11}$.

Por su parte, Agustín de Betancourt reconstruyó en San Petersburgo los muros de canalización en piedra de granito del río Moika a la altura de los «Establos de la Corte» o «Caballerizas Reales» en 1809, y rehabilitó este edificio en la ori-

${ }^{89}$ El bosquejo del proyecto se encuentra actualmente en la Biblioteca del Instituto de Ingenieros de Transporte de Rusia.

90 "Journal des Voies de Communication», I, 1826, p. 41; Besora I ForX, Roger: op. cit., pp. 121-122; Kuznetsov, Dmitry: op. cit., pp. 390-392.

${ }^{91}$ https://panoramanumismatico.com/. agust...; La Fundación de la Expedición de preparación de los documentos (papeles) del Estado. Museo Betancourt. Universidad Estatal del Transporte de San Petersburgo. En 1815 en la orilla del río Fontanka fue comprado un terreno. Poco después el ingeniero destacado Agustín de Betancourt preparó un proyecto de la futura producción tipográfica. El 28 de agosto de 1818 el Emperador Alejandro I aprobó la institución-el estatuto de la nueva fábrica, que recibió el nombre «La Expedición» de la preparación de los documentos (papeles) del Estado. Desde entonces, la Expedición se convirtió en la única empresa en el Imperio Ruso que produciría billetes, bonos y papel sellado. La Expedición producía no solo los billetes federales pero también el dinero para las afueras del Imperio: Zarato de Polonia, Gran Ducado de Finlandia, stamps duty (eng.) para la América Rusa que en aquel momento todavía no pertenecía a los EE.UU. 
lla izquierda del río Moika donde se alojaba la caballería real ${ }^{92}$. Esta obra le sirvió en cierta medida de modelo para diseñar el proyecto de la Sala de Ejercicios Ecuestres o Picadero (Manezh) de Moscú en 1817 por orden del zar Alejandro I, que decidió en 1817 trasladar temporalmente la corte a Moscú para seguir de cerca la reconstrucción de la ciudad después de ser destrozada por las tropas napoleónicas. Este edificio estaba concebido para albergar una sala de ejercicios ecuestres del ejército en invierno, el interior estaba exento de columnas y cubría una superficie enorme 166 metros de largo por 45 de ancho, que permitía entrenar en su interior a un regimiento de soldados, contaba con una particularidad, la instalación de un sistema de calefacción para mitigar las bajas temperaturas invernales ${ }^{93}$.

En cuanto al emplazamiento del Manezh buscó el lugar más adecuado y realizó numerosos paseos por los alrededores del Kremlin hasta encontrar el más conveniente. El emperador Alejandro I le había ordenado construir el Manezh junto al puente Borovitski, pero Betancourt escogió un lugar que permitiera incluir el nuevo edificio en el paisaje histórico sin ocultar el Kremlim. Un detalle interesante e innovador de este edificio que prueba los grandes conocimientos de arquitectura de Betancourt es que su tejado no es simétrico; la parte orientada al sol es más ancha que la orientada a la sombra, la razón se basa en que la cubierta más ancha pueda soportar las fuertes nevadas de Moscú sin derrumbarse ${ }^{94}$. El propio Agustín de Betancourt le envió un ejemplar de la "Description de la Salle d'exercice de Moscou» en 1820 a su hermana Catalina y a su esposo Antonio Monteverde y Rivas en La Orotava (Tenerife), y en una carta desde San Petersburgo con fecha del 10 de junio de 1820 describía brevemente este edificio: «Hace dos años que hice construir en Moscú, de orden del Emperador, una sala para hacer el ejercicio las tropas durante el invierno. A esta sala le di 150 pies ingleses de ancho y más de 500 de largo, sin estar el techo sostenido más que por cuatro muros cosa que no existe hasta ahora en ninguna parte y que ha sido celebrada ${ }^{95}$.

Entre otras aportaciones de Betancourt está el establecimiento de una fundición de cañones en San Petersburgo, además de las ya citadas de Tula y Kazán ${ }^{96}$. Asimismo, hay que tener en cuenta la contribución de Betancourt a las infraestructuras de San Petersburgo como el diseño de puentes, el trazado de nuevos canales imperiales, y caminos en los alrededores de San Petersburgo y en las regiones centrales de Rusia; su obra más destacable fue el camino de San Petersburgo-Novgorod-Moscú ${ }^{97}$.

En relación con la construcción de puentes en San Petersburgo hay que señalar que dada su ubicación en el delta del Neva, que constituye la gran avenida

92 Besora i Foix, Roger: op. cit., p. 97.

93 Kuznetsov, Dmitry: op. cit., pp. 5-13.

94 González Tascón, Ignacio (dir.): Betancourt..., op. cit., pp. 262-284.

95 AHBC. Leg. 9543. Carta n. ${ }^{\circ}$ 40. Agustín de Betancourty Molina, a su cuñado Antonio Monteverde y Rivas, en La Orotava, de fecha 10 de junio de 1820. Véase Cullen, Juan: op. cit., pp. 251-254.

${ }_{96}$ Padrón Acosta, Sebastián: op. cit., p. 45.

${ }^{97}$ http://fundacionorotava.es/betancourt/biography/13/. 
de agua de la ciudad, como la avenida Nevski es la arteria vertebradora urbana de la misma, los puentes han sido vitales para San Petersburgo desde su fundación, aun con la oposición de Pedro I el Grande, que prohibió la construcción de grandes puentes en la llamada "Venecia del Norte»; actualmente existen más de 340 de todos los tamańos, estilos y colores. Con Agustín de Betancourt se inició la construcción de puentes con características modernas; consideraba que cualquier puente, estructura o construcción debía tener un equilibrio apropiado entre las dimensiones correctas, la buena construcción y el criterio estético, es decir, la belleza ${ }^{98}$.

En definitiva, Agustín de Betancourt como ministro de Obras Públicas y presidente de la Comisión de Construcciones y Obras Hidráulicas fue el autor de los planos de numerosos puentes rusos. En 1812 proyectó el primer gran puente fijo de arco en Rusia, era un puente de madera sobre el pequeño Neva entre las islas Kámennyi y Aptékarski, el llamado puente de Kamennoostrovski, que entró en funcionamiento en 1813; Agustín de Betancourt lo planteó con estribos de piedra, y siete tramos en arco de madera con uno central más largo de 25 metros, y cimentado sobre pilotes apoyados en el fondo del río. Este puente sería sustituido en 1854 por otro también de madera, hasta la construcción del actual en 1954. Hoy en día se conoce popularmente en los barrios que comunica como "Betankurovsky»"

A la vista de su experiencia no es de extrañar que en 1820 Agustín de Betancourt recibiera el encargo de reformar el puente de San Isaac, que fue el primero construido sobre el gran Neva en 1727 por orden de Aleksandr Menshikov, el hombre fuerte de Pedro el Grande, y primer gobernador de San Petersburgo, para unir su palacio en la isla Vasiliesvsky con el barrio del Almirantazgo. El puente tenía un carácter provisional, se instalaba después del deshielo de la primavera, y se retiraba en otońo cuando el río comenzaba a helarse; por lo que se le encargó a Agustín de Betancourt en 1820 una alternativa, llegó a la conclusión de que debido a las dificultades de cimentar en el fondo del cauce del río era desaconsejable la construcción de uno fijo, y propuso construir uno de madera soportado sobre pilas flotantes que descansaban sobre 15 barcazas, y al mismo tiempo se construyeron a ambos lados del puente embarcaderos con escaleras de granito que descendían hasta el mismo nivel del agua ${ }^{100}$.

Era un puente de gran vistosidad y de una arquitectura muy hermosa, como se puede apreciar en las imágenes que se conservan de él, una vez más se demostró la gran experiencia de Betancourt en los cálculos y las técnicas a la hora de diseñar los puentes; sin embargo, los puentes soportados sobre barcas presentaban problemas y con el tiempo hubo que demolerlo debido al desarrollo urbano de San Petersburgo, y en 1851 fue sustituido por el actual puente de Nicolás de hierro y granito ${ }^{101}$. En 1820 había publicado sus "Plans du pont des bateaux sur le Gran Neva», y actual-

\footnotetext{
98 Besora i Foix, Roger: op. cit., p. 105.

99 http://fundacionorotava.es/betancourt/biography/13/.

100 BESORA I FoIX, Roger: op. cit., pp. 116-117.

101 Fernández González, José, Cabrera González, Abelardo y Curbelo Cruz, José
} Antonio: op. cit., p. 70. 
mente del puente de San Isaac sólo permanece como recuerdo un monolito de granito rosa en la orilla derecha del Neva en la isla de Vasiliesky. Por otra parte, construyó varios puentes más, y entre ellos se encontraba uno sobre el río Izhora, en San Petersburgo, el de Slavianka en la carretera de Moscú, uno de arco en el parque del palacio de Catalina en Tsárskoye Seló, los de Ijor, Peterhot, Tula, el de Babina sobre el río Rauna, cerca de San Petersburgo, el de Lubani a 100 kilómetros de San Petersburgo, el de Tchudina sobre el río Kerest, a 130 kilómetros, el de Holopje Polesti, y los del camino a Narva ${ }^{102}$.

Gran parte de las competencias de Agustín de Betancourt como director del «Comité de Construcciones y Obras Hidráulicas» consistía en dirigir la construcción y el cuidado de los canales para moldear la topografía de la ciudad atravesada por numerosos riachuelos y las crecidas del Neva. En septiembre de 1816 el zar les encargó a De Wolant y a Betancourt la construcción del canal de Obvodny entre la fábrica Izhora y San Petersburgo ${ }^{103}$. Es el canal más largo de San Petersburgo, mide 8 kilómetros de largo y 21 metros de ancho, y en algunos tramos llega a 40 metros; recibía el caudal del río Neva cerca de la Alexander Nevski Lavra, las paredes del canal se construyeron con piedra de granito; este canal atravesaba los suburbios de la ciudad de la parte meridional, y terminaba cerca del puerto marítimo. A lo largo del siglo xix era la principal arteria artificial de agua de la ciudad, y constituyó un elemento importante para el desarrollo industrial de San Petersburgo $^{104}$. Otros importantes canales según los proyectos de Betancourt fueron el de Ládoga, en el que se empleó para la excavación la draga que en su día había diseñado Betancourt, y el Canal de la Derivación, al sur del monasterio Alejandro Nevski ${ }^{105}$.

Aunque el gran proyecto de Betancourt era la creación del «Canal Alejandrino", que uniría las aguas del Báltico con las del mar Caspio y el mar Negro, y según Betancourt si se realizaba este proyecto inmortalizaría al zar Alejandro $I^{106}$. En este sentido realizó varias obras importantes en diversos canales, como en el de Tíjvinka, el Mariinsky o el de Vyshni Volochok, y construyó el canal del Norte. En el proyecto de la construcción de la Feria de Nizhni Novgorod diseñó en 1820 un canal en forma de herradura a partir del lago Mescherski con el fin de que los barcos pudieran desembarcar las mercancías justo al lado de las tiendas, y en esas mismas fechas se emplearon los primeros barcos de vapor en el río Volga ${ }^{107}$.

También hay que adjudicarle a Agustín de Betancourt el proyecto del primer ferrocarril en Rusia, lo diseñó con un ancho de vía superior al de las vías euro-

102 http://fundacionorotava.es/betancourt/biography/13/; Fernández GonZÁLez, José, Cabrera González, Abelardo y Curbelo Cruz, José Antonio: op. cit., p. 61.

${ }^{103} \mathrm{http}: / /$ fundacionorotava.es/betancourt/biography/.

104 http://www.wikiwand.com/. Obvodny_Canal.

105 Kuznetsov, Dmitry: op. cit., pp. 562-563. Reconstrucción del Canal del Ládoga, y pp. 577-580. El Canal de Derivación.

106 Fernández González, José, Cabrera González, Abelardo y Curbelo Cruz, José Antonio: op. cit., p. 59.

107 http://fundacionorotava.es/betancourt/biography/13/. 
peas, en previsión de futuras invasiones occidentales, porque había sido testigo de la ocupación napoleónica en España y Rusia; casualmente son los dos únicos países de Europa que tienen un ancho mayor de las vías que el resto de los países europeos; sin embargo, no existe ninguna certeza de que esta fuera la razón, sino que son meras hipótesis ${ }^{108}$. Pero será en 1830 cuando los inventores rusos Cherepánovs padre e hijo, siguiendo el proyecto de Betancourt fabricaron la primera locomotora de vapor rusa entre San Petersburgo y Tsárkoye Selò, que conectaba los palacios imperiales de Pavlovsk en San Petersburgo con los de Tsárkoye Selò. El primer ferrocarril de Rusia se inauguró en 1837 con un recorrido de 17 kilómetros ${ }^{109}$.

En efecto, uno de los grandes inventos de Agustín de Betancourt fue la puesta en práctica de una potente draga de vapor, a base de una cadena de cangilones, que había inventado para extraer arenas y fango de los fondos del puerto de Kronstadt, una pequeña isla fortificada en el golfo de Finlandia, que era el puerto comercial y militar de San Petersburgo, y para abrir un canal que lleva el nombre de Betancourt; esta draga se había comenzado a fabricar en Izhora en 1810, y entró en funcionamiento en 1812; fue financiada por el Ministerio de la Marina de Guerra, y estuvo operativa durante una veintena de años ${ }^{110}$. El propio Betancourt explicaba el diseño de la draga en una carta dirigida a su hermano José en 1814, en la que afirmaba lo siguiente: «He hecho una máquina para limpiar el puerto de Cronstat, movida por una bomba de fuego, cuyos planos me viste trabajar en París, y ha salido con tanta perfección que cada dos minutos saca una vara cúbica de fango a 20 pies de profundidad ${ }^{111}$. Este invento de la draga a vapor de Agustín de Betancourt había sido rechazado por la Comisión de Marina de España en $1792^{112}$.

De particular trascendencia fue su gran proyecto de la feria de Nizhni Nóvgorod, inaugurada en 1822 en la confluencia de los ríos Volga y Oka, y así la describía el propio Agustín de Betancourt a su hermana María del Carmen (Maruca) en una carta en 1820: «Esta feria será una de las cosas más curiosas que habrá en Europa [...] los edificios son para contener tres mil tiendas espaciosas, delante de las cuales hay una galería sostenida por tres mil doscientas columnas de hierro fundido. Además hay varios edificios para la habitación del Gobernador, para la bolsa, café, salas bre, 1964.

108 Gómez Tabanera, José Manuel: «Otoño en Moscú», $A B C$, Madrid, 29 de noviem-

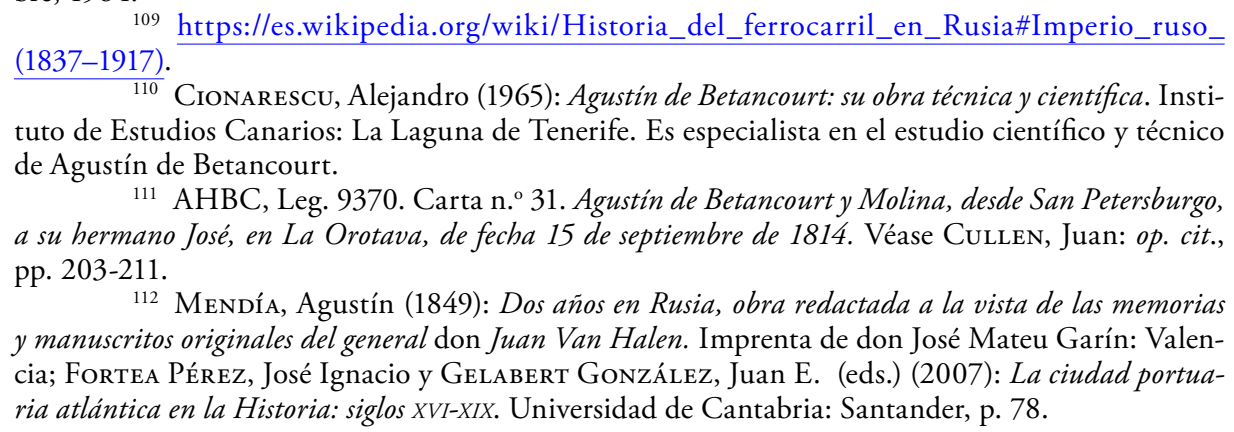


de asambleas generales, tres iglesias etc. ${ }^{113}$. Los productos para esta feria llegaban a través del río Volga, en barcos de vapor que habían sido introducidos por Betancourt en los ríos rusos ${ }^{114}$.

Agustín Agustinóvich Betancourt, como era conocido en Rusia, o como el español-ruso, unió su destino vital a una ciudad que ha sido un «milagro y un misterio». Actualmente sus restos descansan en el Panteón Nacional de Hombres Ilustres de Rusia en el cementerio Lazareski, junto al monasterio de Alejandro Nevski, al lado de otros grandes personajes de la historia de Rusia. El mausoleo fue diseńado por su discípulo y arquitecto Auguste de Montferrand con una monumental columna de hierro fundido de siete metros y un bello epitafio como último homenaje al «Maestro».

HIC JACET

NOBILIS ET DOCTIS DOMINUS

AUGUSTINUS DE BETANCOURT, N.INSULIS CANARIS AD MCCLVIII

O. PETROPOLI ADON MDCCCXXIV

VIATOR ORA PRO SALUTE SUA

AQUÍ YACE

EL NOBLE Y SABIO SEÑOR

AGUSTÍN DE BETANCOURT NACIDO EN LAS ISLAS CANARIAS

EN MCCLVIII

FALLECIDO EN SAN PETERSBURGO EN MCCCXXIV

AL VISITANTE ROGAMOS UNA ORACIÓN POR SU ALMA

\section{CONCLUSIONES}

Aunque no lo parezca, el zar Alejandro I y Agustín de Betancourt tenían bastantes cosas en común y muchas diferencias de modo que los matices se hacen necesarios; ambos eran ilustrados y compartían las ideas de Rousseau dentro del clima cultural e intelectual de las reformas de su época; buscaban el progreso de la sociedad, tenían una gran capacidad de trabajo, y se empeñaron en hacer de San Petersburgo una ciudad moderna y cambiar la historia de Rusia. Así pues, dejaron su huella en la ciudad de San Petersburgo, y también reconocemos en la actualidad la capacidad de esta ciudad para superar las crisis y los grandes acontecimientos de su historia, permaneciendo siempre fiel a sí misma y a sus sueños.

Agustín de Betancourt se movió entre las ideas de la Ilustración, de la Revolución Francesa, de la Revolución Industrial, del Imperio napoleónico y del Libera-

${ }^{113}$ AHBC. Carta n. ${ }^{\circ}$ 38. Leg. 9542. Agustin de Betancourty Molina, desde San Petersburgo, a su hermana Maria del Carmen, en La Orotava, de fecha 10 de junio de 1820. Véase Cullen, Juan: op. cit., pp. 241-245.

${ }^{114}$ Padrón Acosta, Sebastián: op. cit.p. 47. 
lismo. Llegó a la corte afrancesada e ilustrada del zar Alejandro I cuando ya tenía cincuenta años, y contribuyó al desarrollo urbano, industrial y cultural de Rusia. Unía la ciencia, la técnica y las bellas artes, dio lo mejor de sí mismo como ingeniero, arquitecto y urbanista en San Petersburgo, Nizhni Nóvgorod, Moscú y otras ciudades rusas. Demostró un gran talento y dejó su sello en la construcción de uno de los núcleos urbanos más espléndidos y armoniosos de Europa como fue San Petersburgo, que hoy no sería la misma ciudad sin Agustín de Betancourt. Es quizás el español más conocido en San Petersburgo por haber contribuido en gran medida al desarrollo urbanístico de la ciudad. Por otra parte, los resultados de la transformación urbana de San Petersburgo en las primeras décadas del siglo xix fueron asombrosos, y una parte importante se debe a las obras realizadas por Agustín de Betancourt, que puso en práctica las técnicas y la experiencia adquirida en Madrid, París y Londres al servicio de Alejandro I, por lo que se ha convertido en una leyenda en San Petersburgo.

En la mentalidad de Agustín de Betancourt se unía una parte canaria, otra española y una rusa. Amó a su patria, y como afirmaba el gran filósofo español Miguel de Unamuno (1864-1936) «le dolía España» porque fracasaron las ideas progresistas, y se perdió la oportunidad de impulsar a la sociedad española hacia la modernidad. Fue un ingeniero polivalente del periodo de las Luces, un experto en la técnica, en las matemáticas y la hidráulica; además era un especialista altamente cualificado, se le podría definir como un "hombre todo terreno», encarnaba la mentalidad de su época, pero al mismo tiempo era una persona singular, porque desde Canarias, pasó a Madrid para realizar una gran carrera, para integrarse en los procesos de la circulación de los «saberes» a escala europea, y configuró la profesión de ingeniero. Por otro lado, pasó media vida viajando y cada uno de sus viajes tenía una razón específica. Con su formación y sabiduría respondió a las estrategias de modernización acelerada tanto de España como de Rusia, y le tocó vivir en un mundo profesional de profundos cambios, en medio de una Europa agitada por los cataclismos políticos y militares entre 1780 y 1815. Con Betancourt nació la Ingeniería Civil en Rusia.

Hay que desmentir categóricamente que Betancourt practicara actos de «espionaje industrial» como afirman ciertos historiadores sin aportar fuentes que justifiquen especialmente dichas tesis, incurriendo la mayor parte de las veces en contradicciones. En definitiva, se ha fabricado una «leyenda negra» con respecto a que copió la máquina de vapor de James Watt, cuando no pudo examinarla atentamente, y sólo se conformó con verla detrás de un muro unos segundos durante su viaje a Inglaterra en 1788, pero gracias a su privilegiada inteligencia consiguió reinventar la "máquina de vapor de doble efecto» y perfeccionarla. Su vida estuvo marcada por las circunstancias políticas españolas que le obligaron a exiliarse profesionalmente a San Petersburgo, por las económicas y las familiares. Él mismo habla en su correspondencia de la situación política de España a comienzos de 1800, que se hallaba en un periodo turbulento por la evolución política, por su enfrentamiento con el todopoderoso Manuel Godoy, valido de Carlos IV, y por la política absolutista de Fernando VII, que hizo cerrar la Escuela de Ingenieros de Madrid fundada por el propio Betancourt, porque la consideraba un foco «liberal e ilustrado» y la 
convirtió en una "Escuela de Tauromaquia», pero a pesar de todas las desgracias que soportó a lo largo de su vida supo mantener la dignidad hasta el final.

Rusia fue su patria de adopción, y formó parte de sus afectos. Pero sobre todo se mantuvo unido a sus orígenes canarios hasta su muerte; sin embargo, los últimos ańos de su vida estuvieron marcados por la tristeza, debida a la incomprensión del zar Alejandro I, a quien había servido con total y absoluta lealtad, y a las desgracias familiares. Es una figura universal que sigue uniendo los lazos entre España y Rusia. Gracias a las iniciativas hispano-rusas se está recuperando su figura, y nos ha dejado obras de ingeniería y arquitectura de marcada relevancia. De una forma global se puede afirmar que la actividad de Betancourt en Rusia marcó la llegada del «ingeniero moderno» a este país.

Por último, San Petersburgo guarda los gustos y las modas arquitectónicas del pasado. Es una exquisita ciudad del arte, y ha alcanzado la inmortalidad literaria; encierra toda la belleza del mundo, pero sólo guarda una parte de la de Rusia, y se sitúa en el territorio de la memoria, y permanece más allá del tiempo. Vivió un momento glorioso con Alejandro I, atento a las modas del tiempo que le tocó vivir, y abierto a las grandes corrientes culturales europeas. San Petersburgo fue un lugar de encuentro superando todo tipo de fronteras, donde se recogieron todas las tradiciones arquitectónicas de Europa. Se convirtió en el paradigma de la nación rusa, no sólo fue un proyecto artístico, y cultural, sino ante todo político.

Finalmente, Agustín de Betancourt manifestó una enorme curiosidad por todas las ramas técnicas. Su sabiduría, talento y trabajo siempre estuvo al servicio del bien público. Gracias a los ciudadanos rusos y en especial a los de San Petersburgo se ha mantenido viva su figura, y se ha convertido en una leyenda en San Petersburgo, lo que no hemos sabido hacer los españoles. 


\section{FIGURAS}

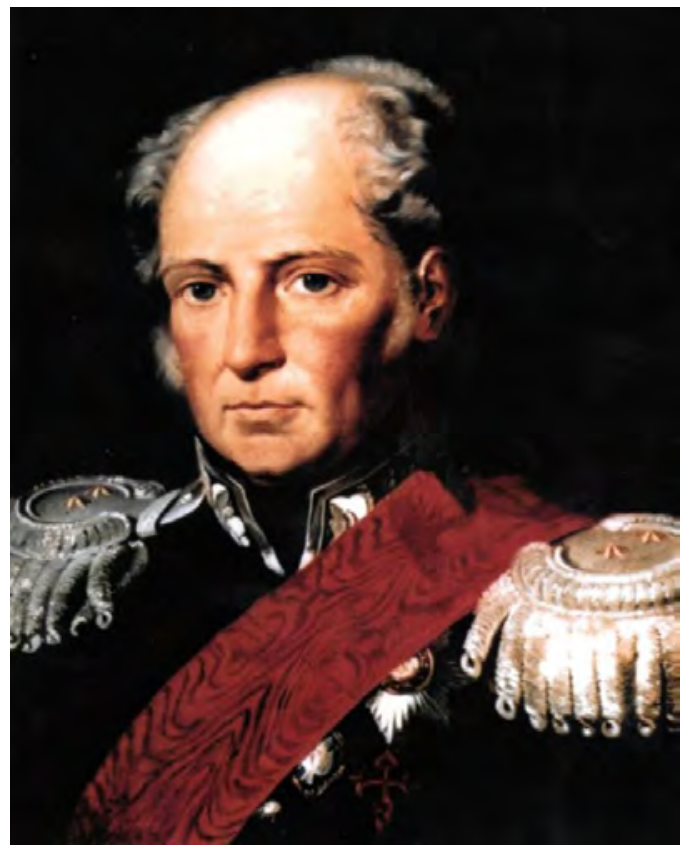

Figura 1. Retrato al óleo de Agustín de Betancourt y Molina (1758-1724), por Platón Tiurin 1859. Fuente: Museo del Ferrocarril de San Petersburgo. 


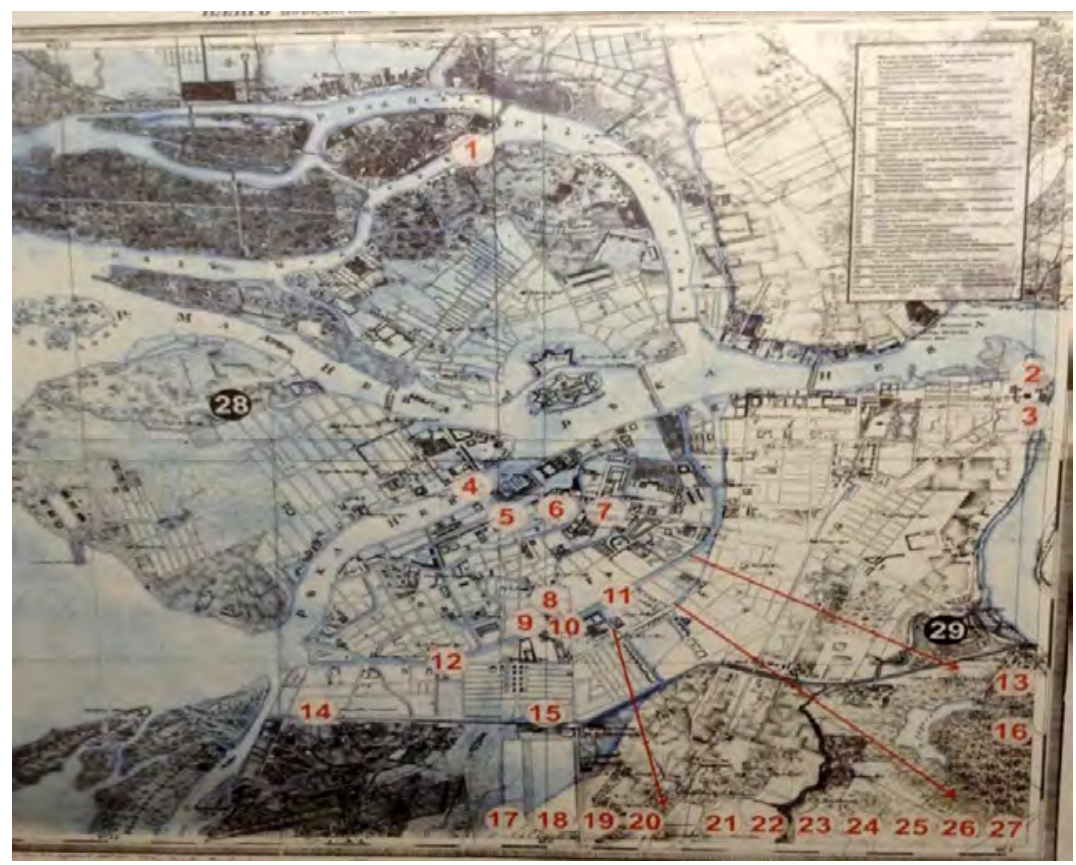

Figura 2. Plano de las obras de A. Betancourt en Rusia. Fuente: Museo A. Betancourt en la Universidad Estatal de Vías de Comunicación de San Petersburgo.

1. Puente Kamennoostróvskiy (puente de la isla de piedra).

2. Aserradero a vapor en Óhta.

3. Iglesia de San Georgio, en el cementerio Bolsheóhtinskoye.

4. Puente flotante (de barcas) de San Isaac.

5. Catedral de San Isaac.

6. El apartamento de Betancourt en la calle Bolshaya Morskaya, donde vivió en 1822-1824.

7. Catedral de Nuestra Seńora de Kazán (restauración de la cruz).

8. Instituto del Cuerpo de Ingenieros de Vías de Comunicación.

9. El apartamento de Betancourt cerca del Instituto.

10. Dirección General de Vías de Comunicación.

11. Comité para las construcciones y obras hidráulicas.

12. Expedición de papeles del Estado.

13. Fábrica de papel moneda del Emperador Alejandro.

14. Puente Bumazhny sobre el canal Bumazhny.

15. Canal Obvodny.

16. Sistemas fluviales de Vyshni Volochók, Tíkhvin y Mariínskaya.

17. Casa de moneda en Varsovia.

18. Tubería de agua de Taitsky.

19. Baño superior en el parque de Catalina, en Tsárskoye Seló.

20. Fuente "Dama con cántaro» («La lechera») en el parque de Catalina en Tsárskoye Seló.

21. Carretera San Petersburgo-Moscú. Reconstrucción (construcción).

22. Manège de Moscú (Picadero de Moscú).

23. Tver. Obras de protección contra inundaciones.

24. Planta de armas de Tula.

25. Planta de fundición de cañones de Kazán.

26. Diseño y construcción de la Feria de Nizhni Nóvgorod. Diseño del plan general para el desarrollo urbano de Nizhni Nóvgorod.

27. Vías de comunicación en las regiones sureñas del Imperio. Diseño de proyectos para su mejoramiento.

28. Cementerio luterano Smolénskoye, en el cual inicialmente fue enterrado Betancourt.

29. Cementerio Lázarevskoye-Necrópolis del Monasterio de Alejandro Nevski (Alexander Nevski Lavra), en el cual volvieron a enterrar los restos de Betancourt en 1979. 


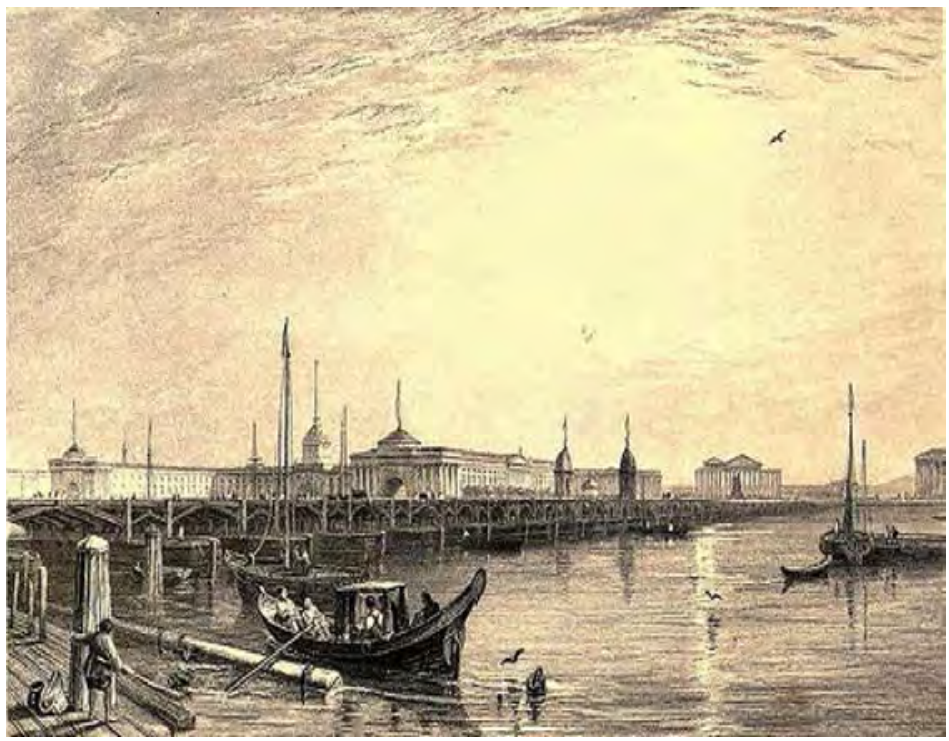

Figura 3. El Almirantazgo, siglo XIX.

Fuente: http://www.odisea2008.com/2011/06/San-petersburgo-y-moscu-en-siglo-XIX.html.

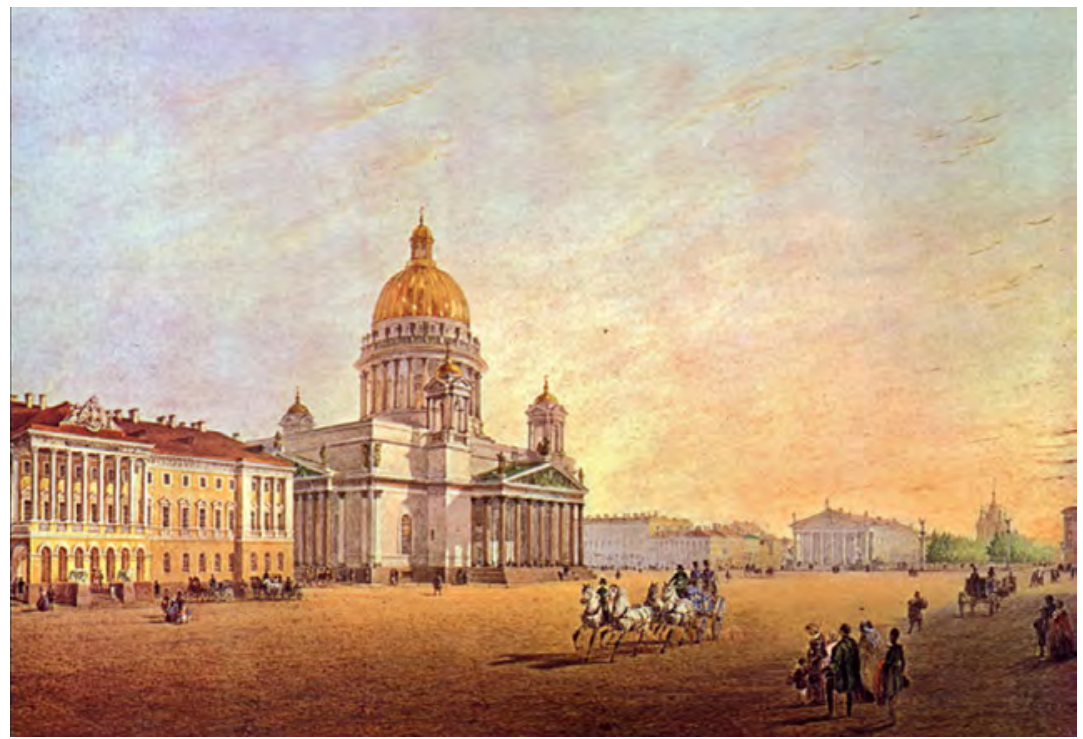

Figura 4. Plaza de San Isaac, siglo xIx.

Fuente: http://www.san-petersburgo.com/sadovnik.htm. 


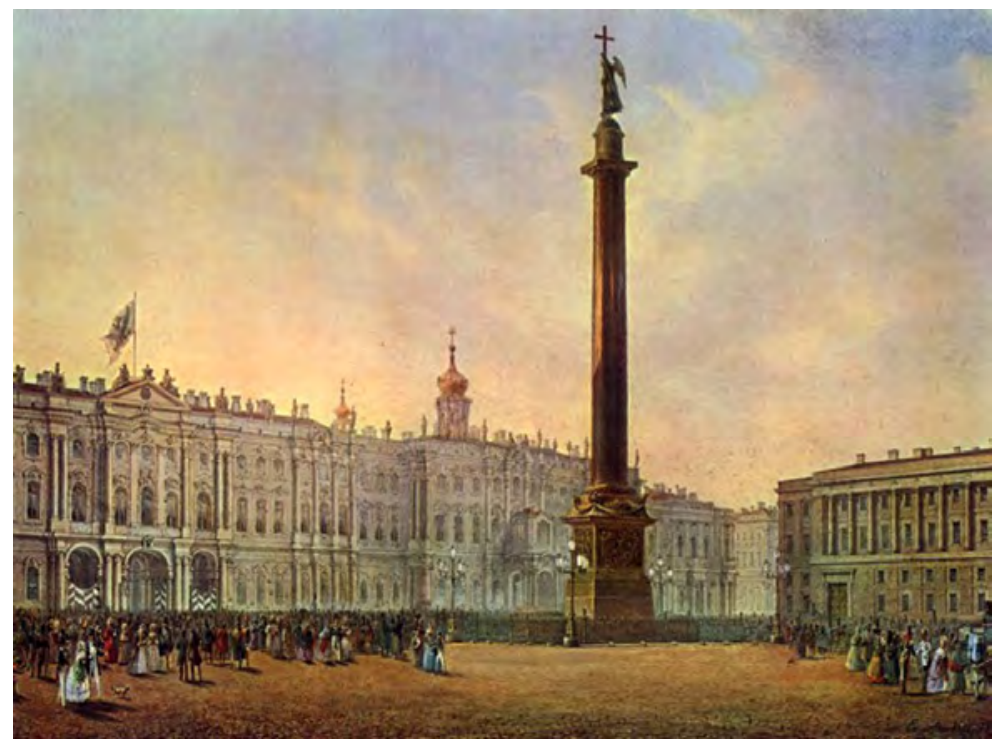

Figura 5. Plaza del Palacio de Invierno, siglo xIx. Fuente: http://www.san-petersburgo.com/sadovnik.htm.

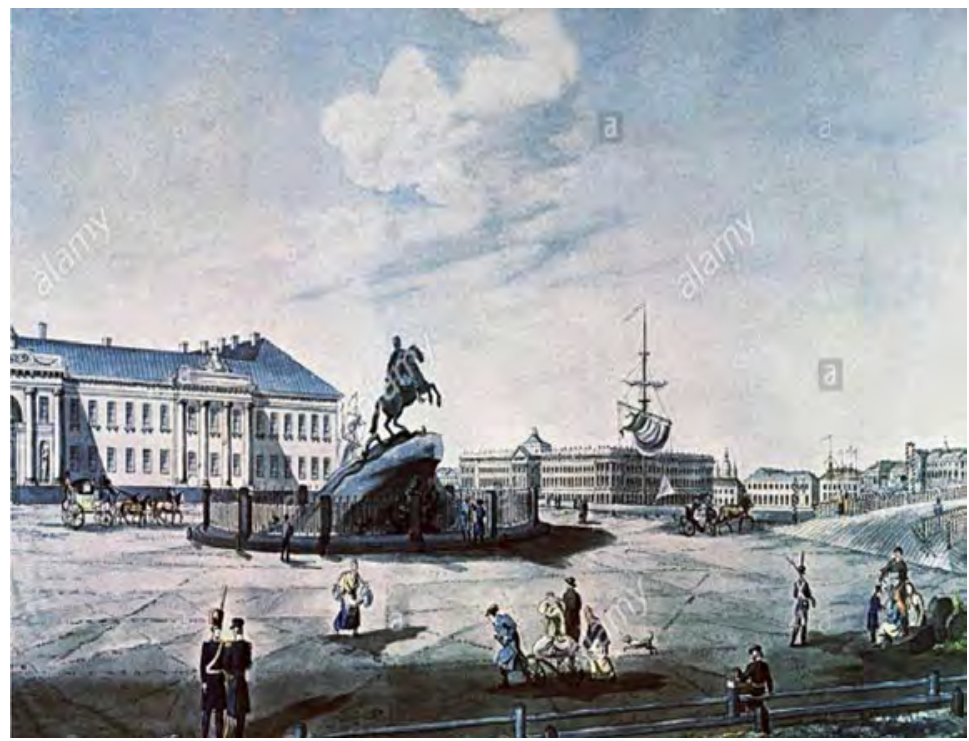

Figura 6. Plaza del Senado, principios del siglo xIx. Fuente: http://www.alamy.es/foto-la-plaza-del... 


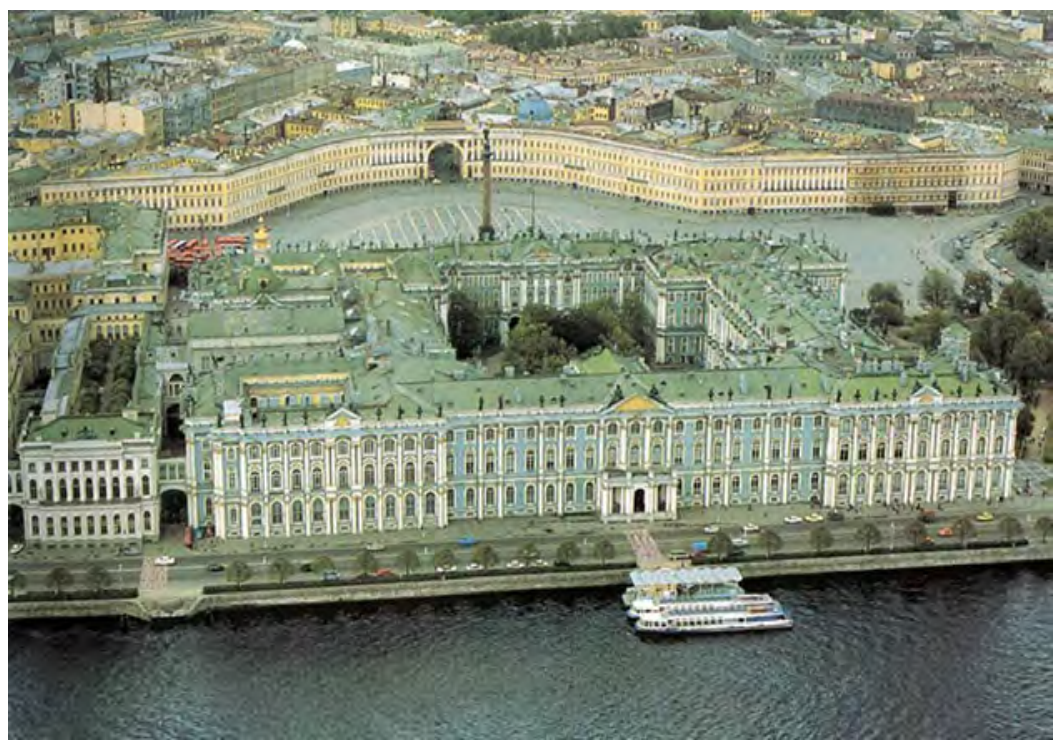

Figura 7. El proyecto de urbanización de la plaza de Invierno fue aprobado por A. Betancourt en 1819. Fuente: http://www.mupart.uv.es.

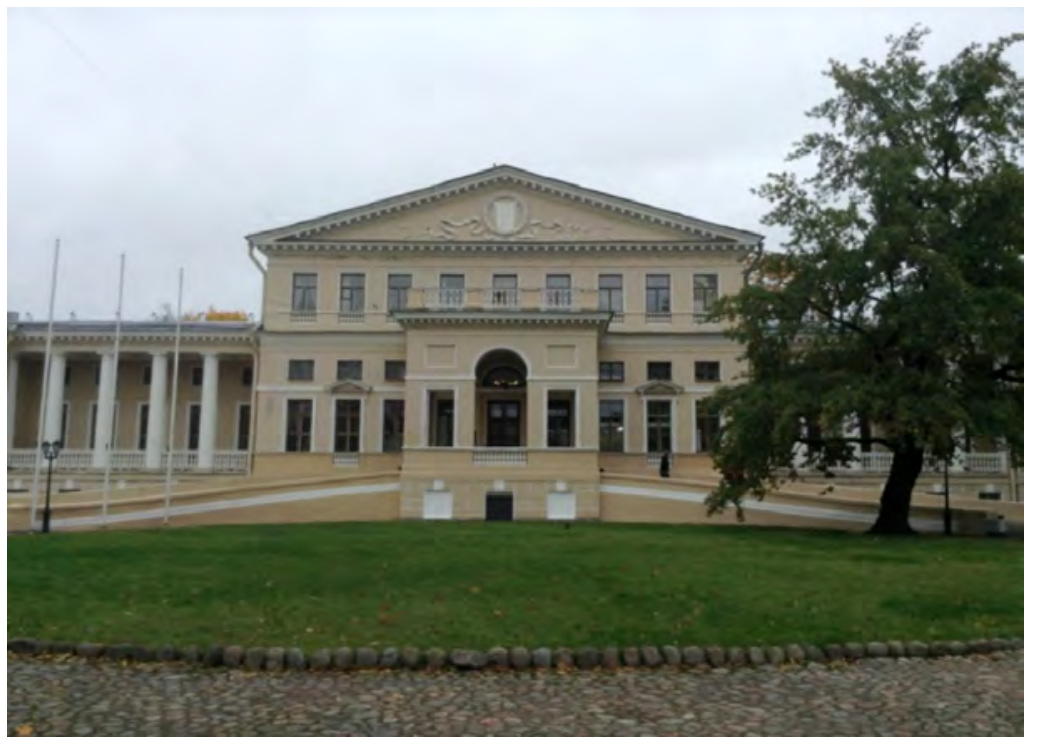

Figura 8. Instituto de Vías de Comunicación fundado por A. Betancourt, 1809. Fuente: Autoría propia. 


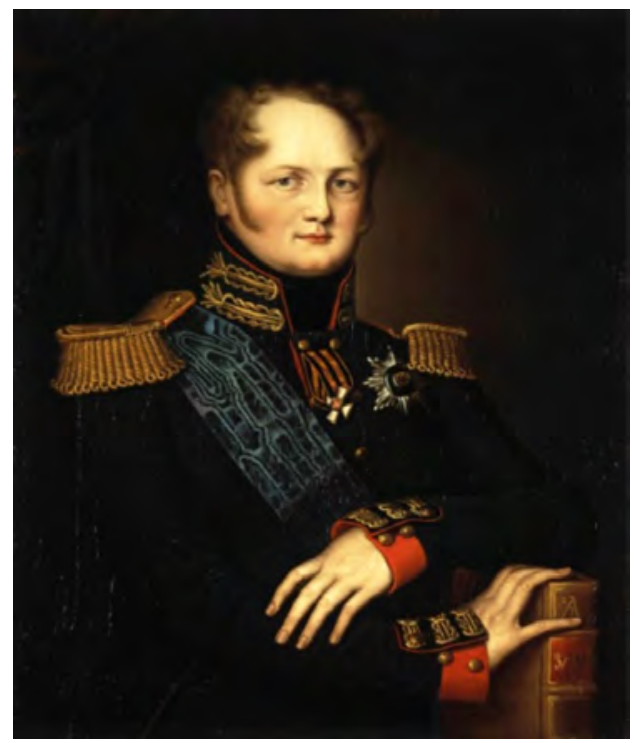

Figura 9a. El zar Alejandro I (1777-1825).

Fuente: http://www.google.essearch?q=imagenes+del+zar+alejandro+\&ie=UTF-8\&oe=UTF.

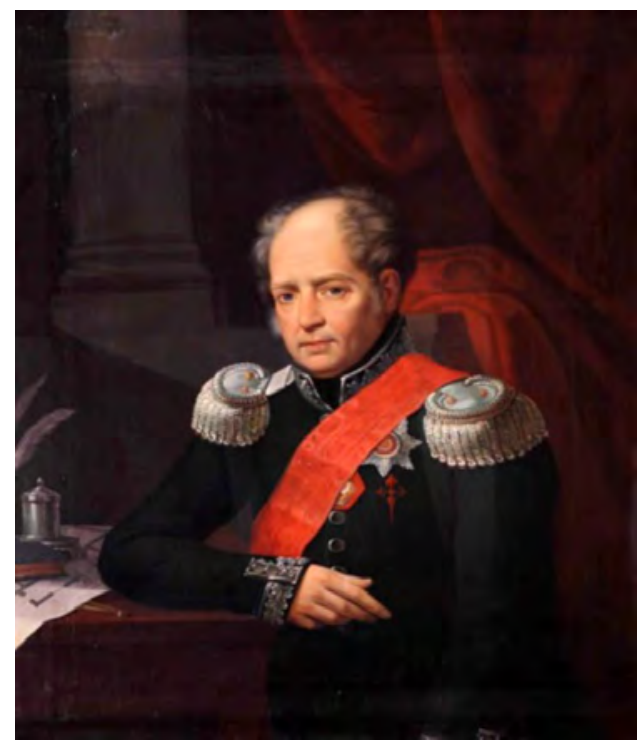

Figura 9b. Agustín de Betancourt (1758-1824). Fuente: Retrato al óleo de Agustín de Betancourt. Imagen cedida por en la Escuela Técnica Superior de Ingenieros de Caminos de Madrid. 


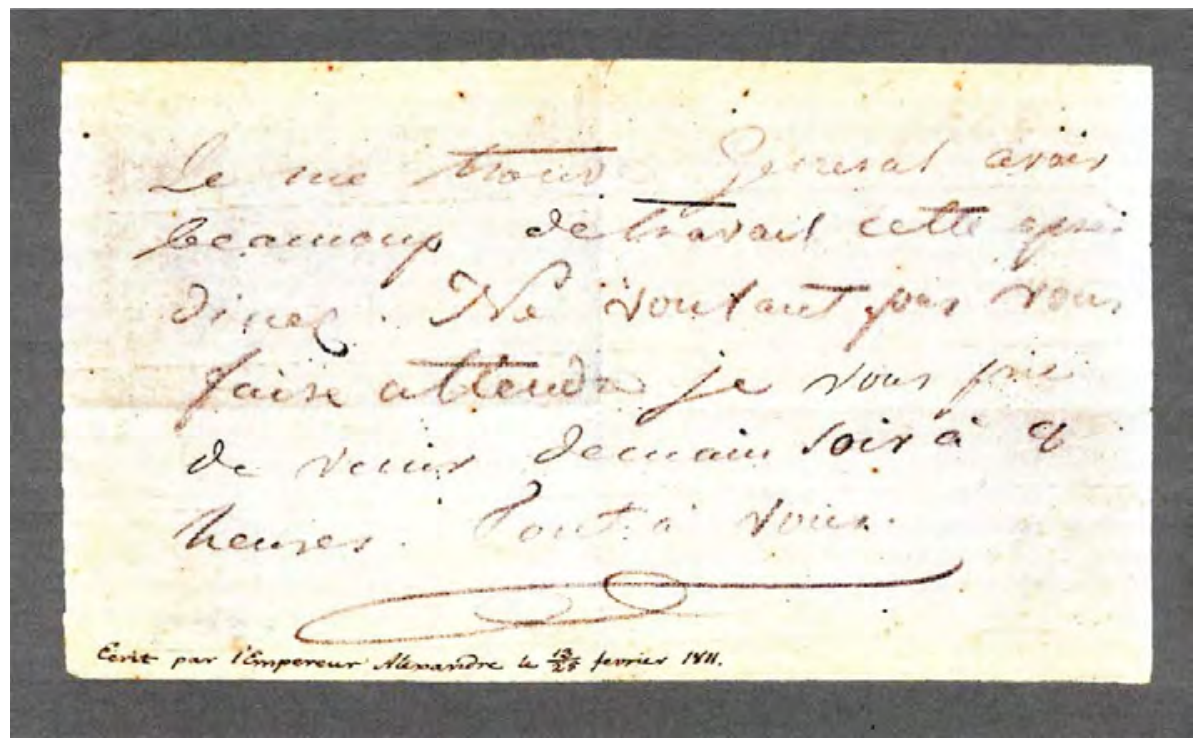

Figura 10. Nota manuscrita de Alejandro I dirigida a A. Betancourt. El original del manuscrito se halla en el AHBC. Fuente: Juan Cullen Salazar. 2008. La familia de Agustín de Betancourt y Molina. Correspondencia íntima. Domibari Editores: Las Palmas de Gran Canaria, p. 211.

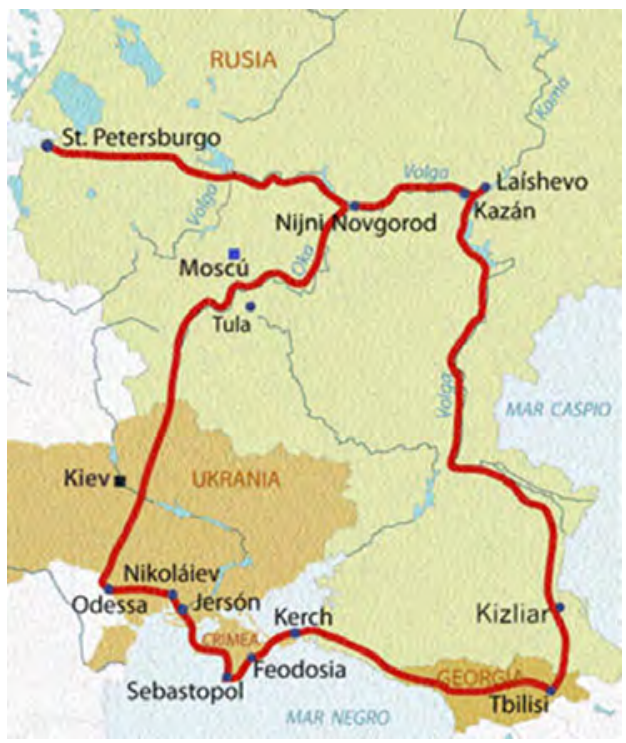

Figura 11. El último gran viaje de A. Betancourt por el Imperio ruso en 1820.

Fuente: http://fundacionorotava.es/betancourt/biography/13/. 


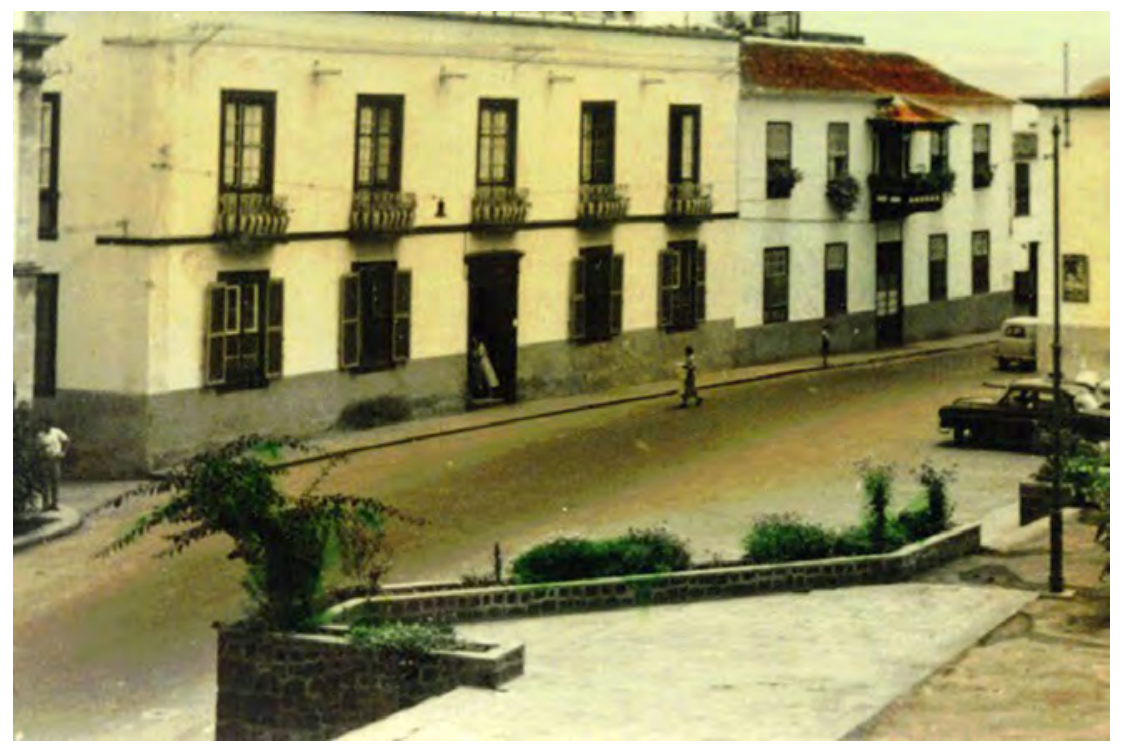

Figura 12. Casa natal de A. Betancourt en

el Puerto de la Cruz (Tenerife) en los ańos sesenta del siglo xx.

Fuente: http://www.google.es/search?q=postales+antiguas+hotel+puerto+de+la+cru.
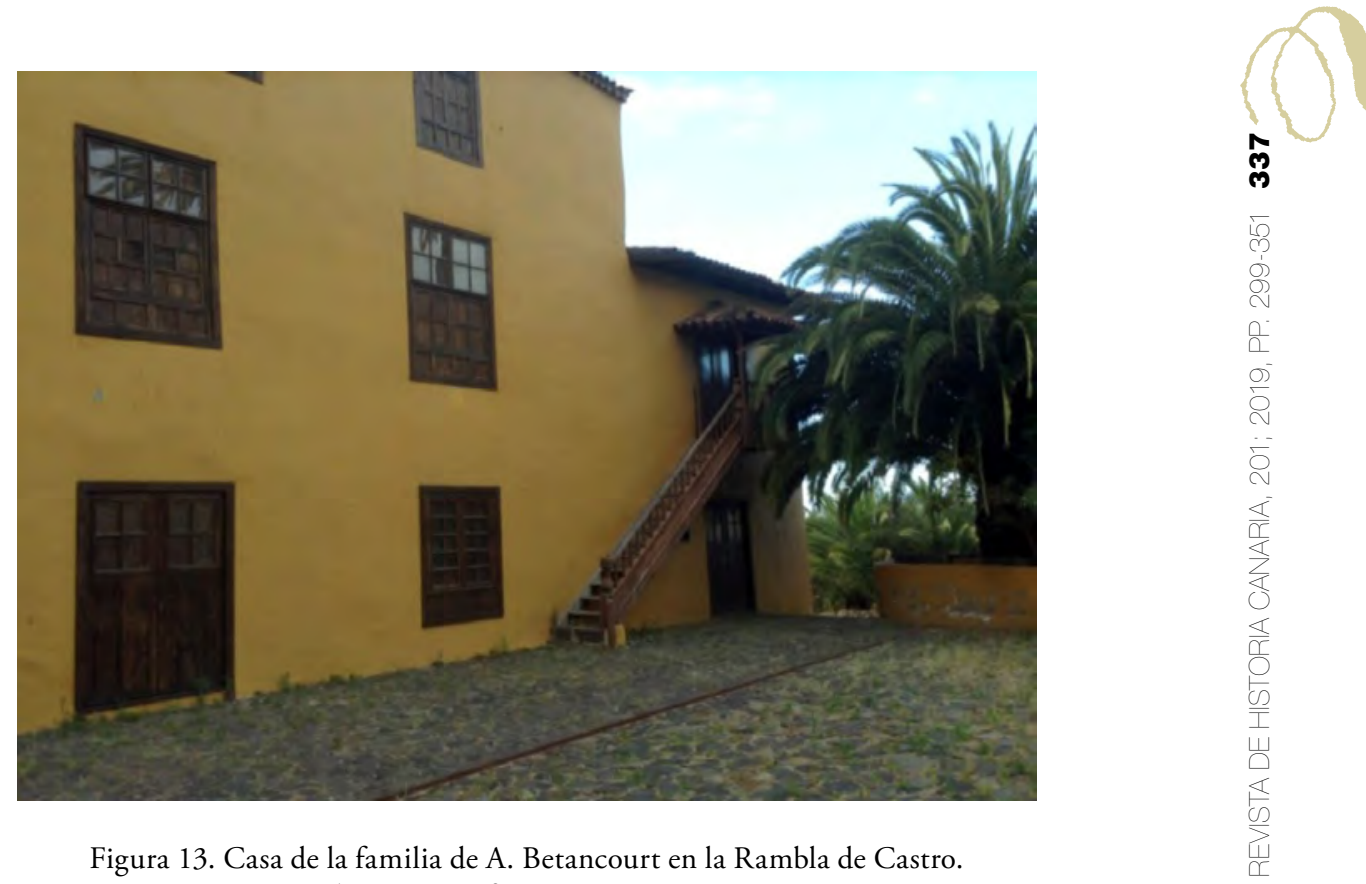

Figura 13. Casa de la familia de A. Betancourt en la Rambla de Castro. Los Realejos (Tenerife). Fuente: Autoría propia. 


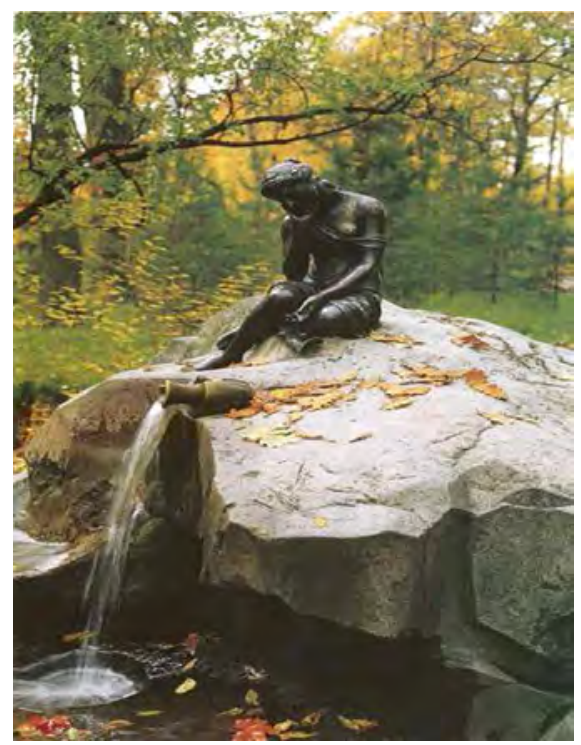

Figura 14. Acueducto a la fuente de la «Joven del cántaro roto» en Tsárskoye Seló.

Fuente: https://sp.depositphotos.com/.

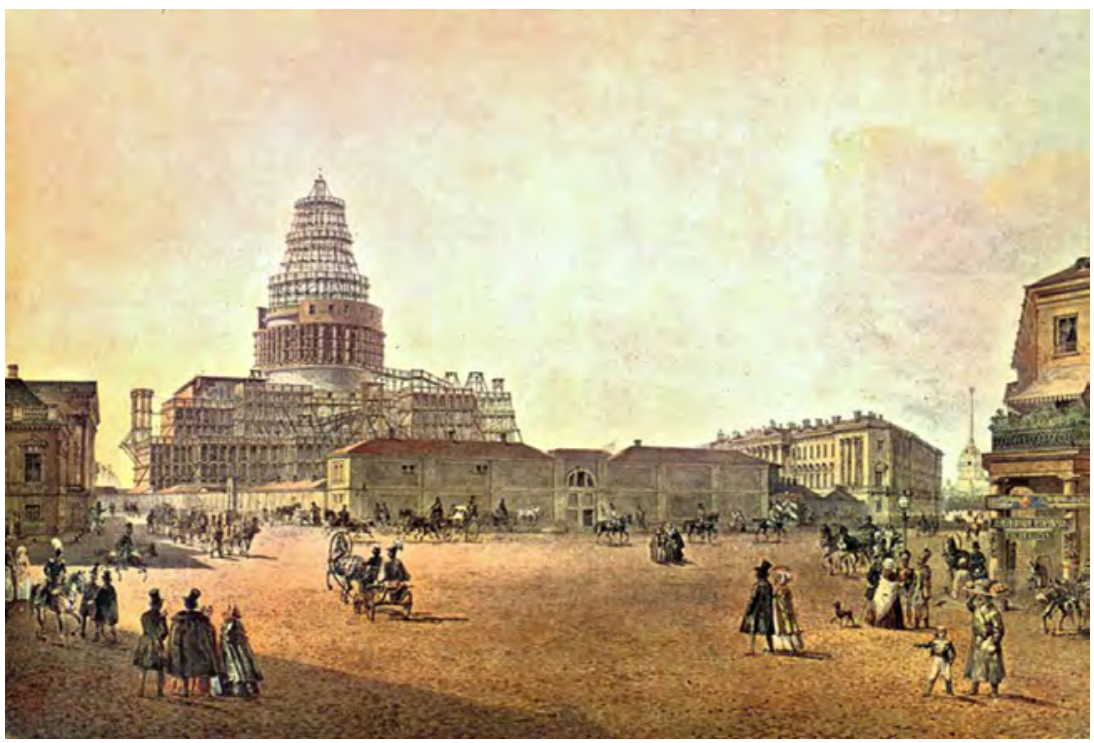

Figura 15. Construcción de la catedral de San Isaac (1818-1858). Acuarela antigua del siglo XIx. Fuente: http://www.san-petersburgo.com/sadovnik.htm. 


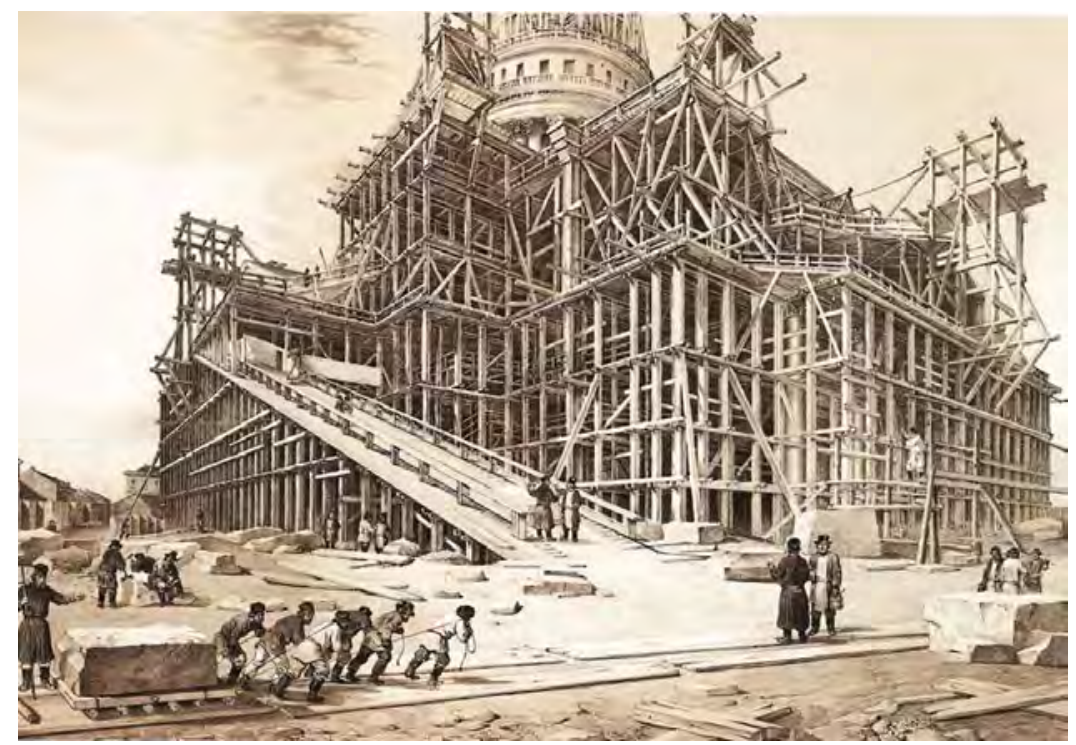

Figura 16. Andamios diseñados por A. Betancourt para la construcción de la catedral de San Isaac.

Fuente: http://www.alamy.es/vista-de-la-catedral-rodeada-por-andamio-de-madera-de-la.

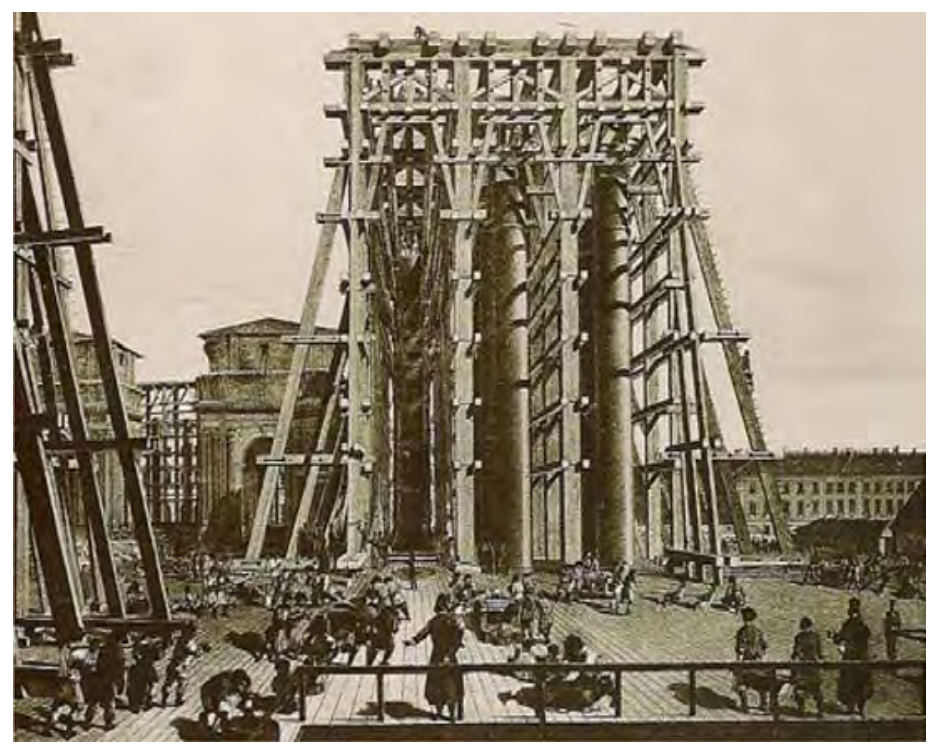

Figura 17. Andamios diseñados por A. Betancourt para instalar las columnas de granito de la catedral de San Isaac.

Fuente: https://www.rbth.com/. articles, 2011/10/03. 


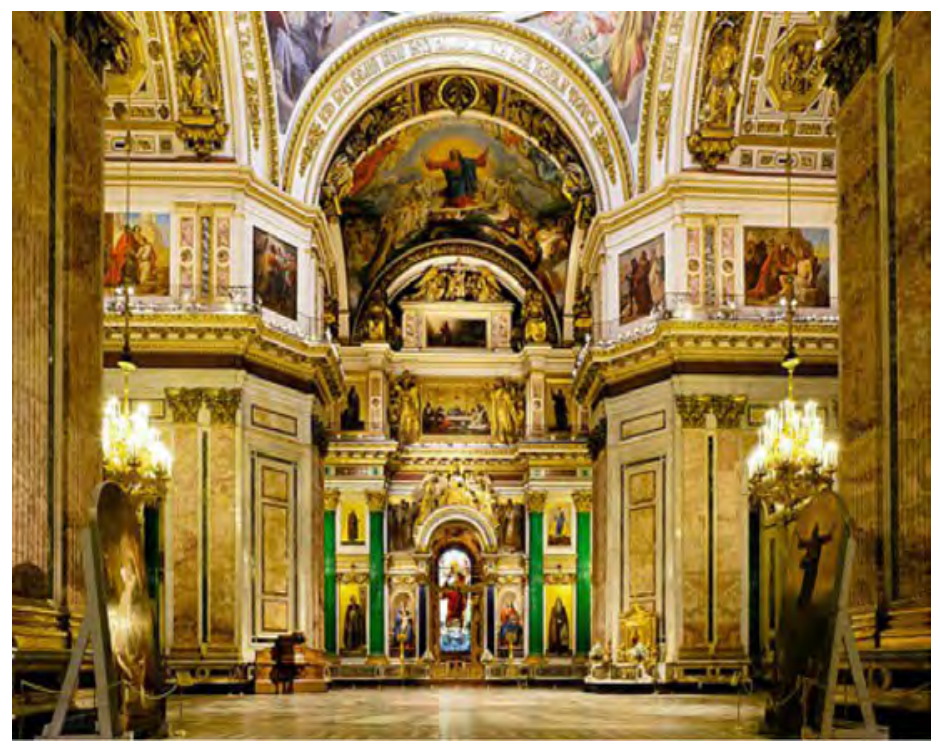

Figura 18. Altar mayor de la catedral de San Isaac. Las columnas de malaquita elevadas según el sistema de andamios diseñado por A. Betancourt.

Fuente: http://www.alamy.es/imagenes/st-isaac-catedral-interior.html.

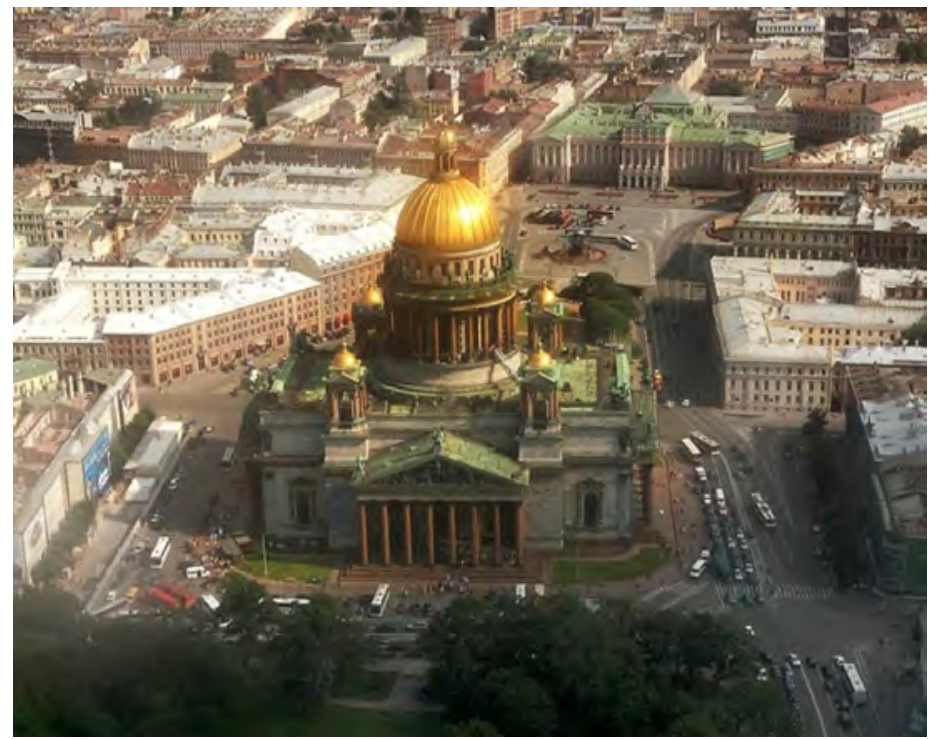

Figura 19. La catedral de San Isaac como uno de los ejes de urbanización en el siglo XIX. Fuente: https://www.alamy.es/imagenes/saint-i. 


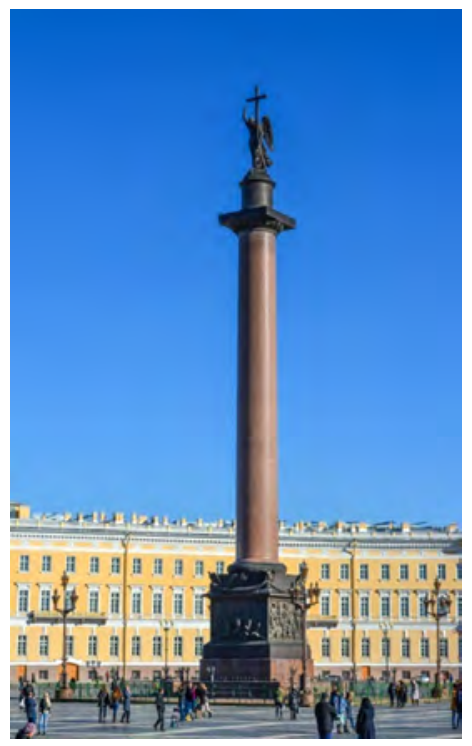

Figura 20. Columna de Alejandro I diseñada por A. Betancourt, construida por Auguste de Montferrand (1829-1834). Fuente: https://es.m.wikipedia.org/wiki/Columna_de_Alejandro.

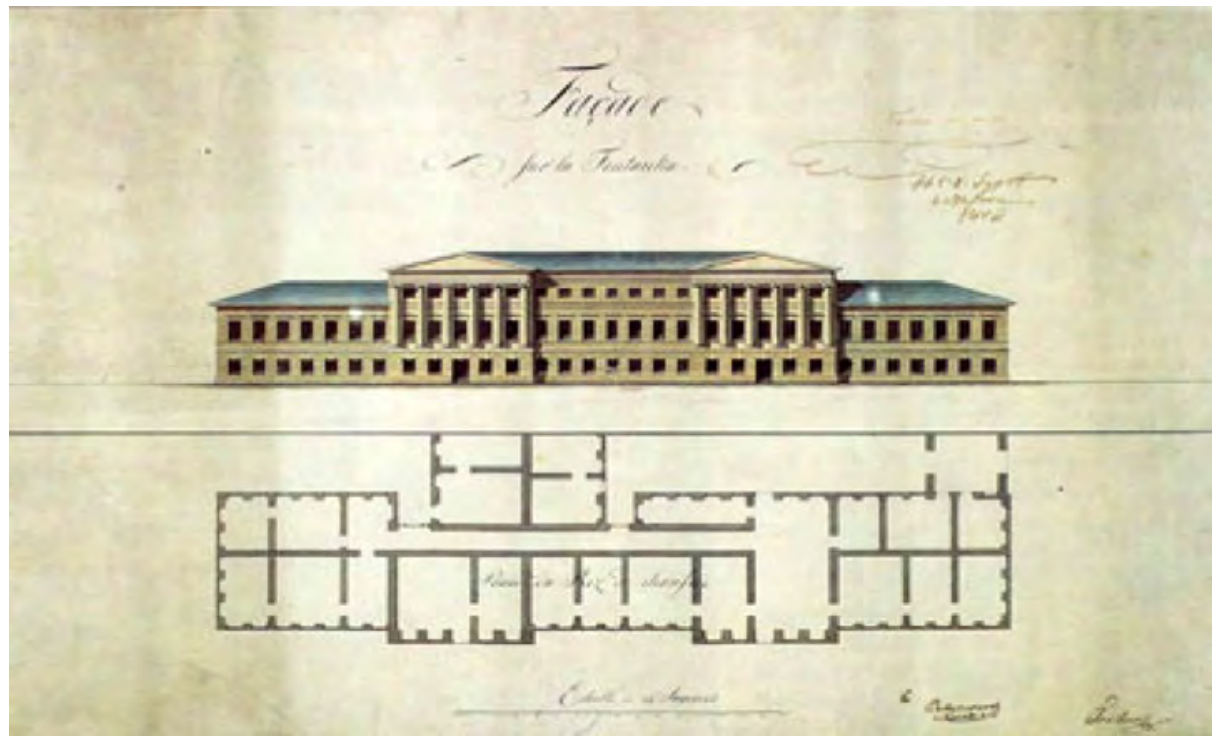

Figura 21a. A. Betancourt levantó los planos y realizó la construcción de la fábrica de papel moneda en 1816-1818 a orillas del río Fontanka.

Fuente: http://fundacionorotava.es/betancourt/about/description/. 


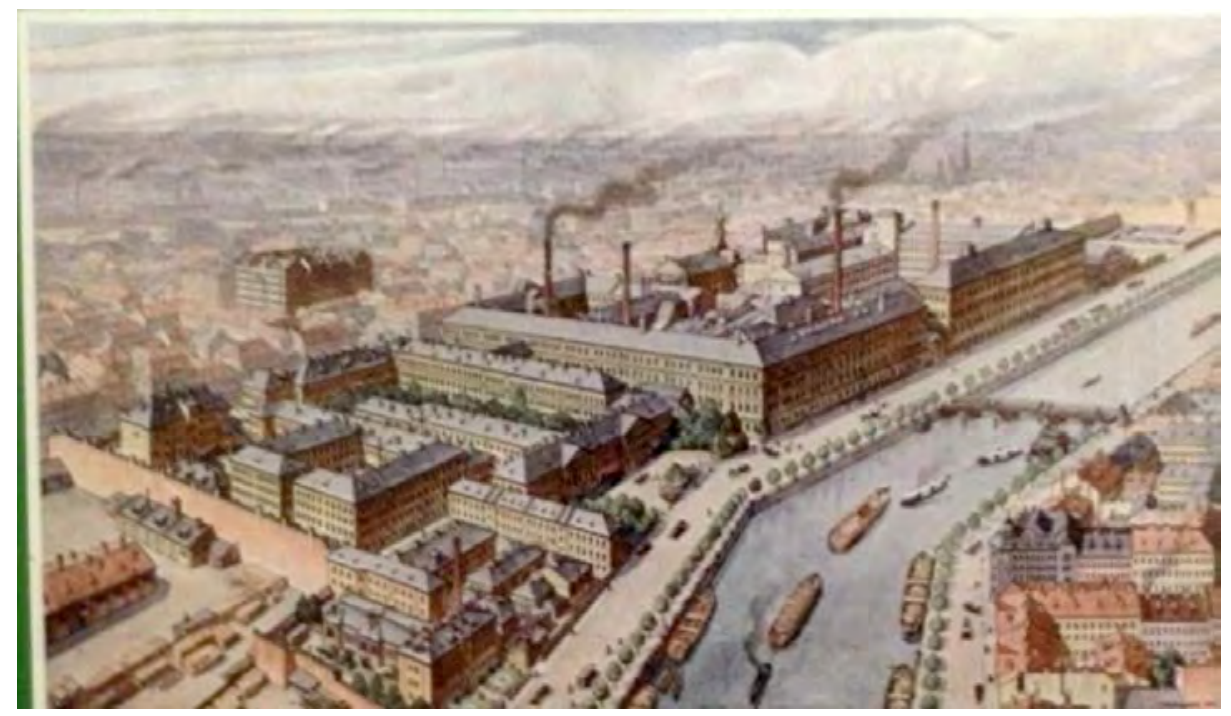

Figura 21a. A. Betancourt levantó los planos y realizó la construcción de la fábrica de papel moneda en 1816-1818 a orillas del río Fontanka.

(2) The Saint-Petersburg Paper Mill: http://spbf.goznak.ru/en/about/history/.

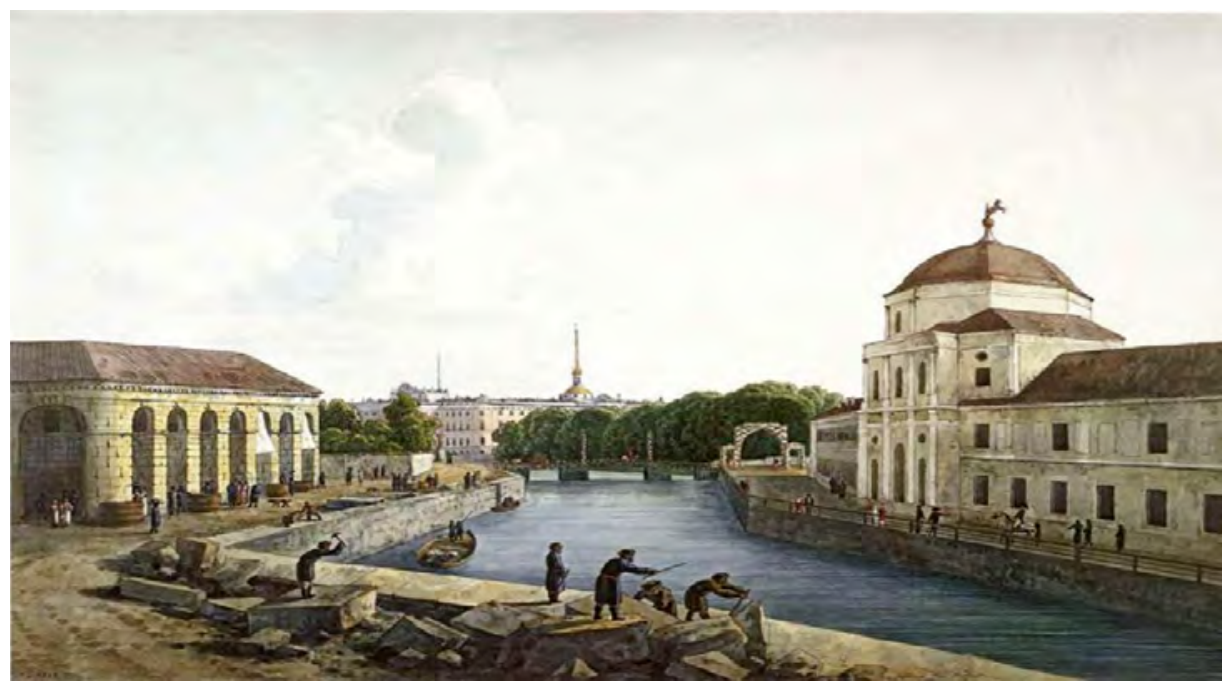

Figura 22. Reconstrucción de muros de canalización del río Moika a la altura de los establos de la Corte (1809), obra de A. Betancourt. Fuente: Besora I Forx, Roger, et alii. 2014. A la luz de San Petersburgo. Madrid. Fundación Esteyco, p. 97. 


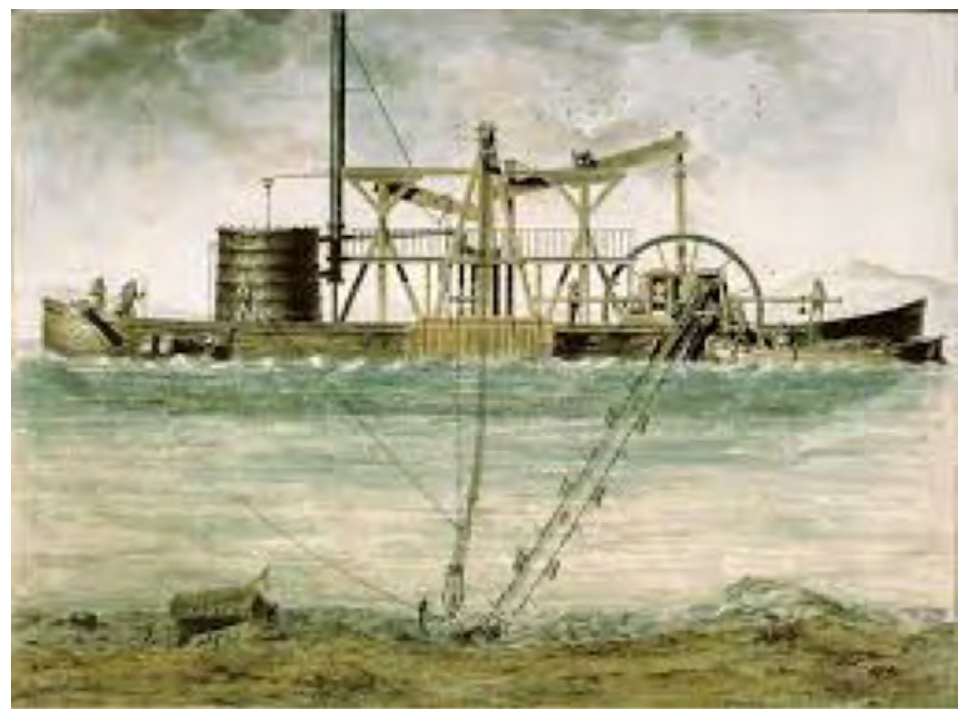

Figura 23a. Imagen de la draga de vapor para limpiar los fondos el puerto de Krondstadt inventada por A. Betancourt en 1810. Fuente: http://www.fundpushkin.org/agustin-de-betancourt/.
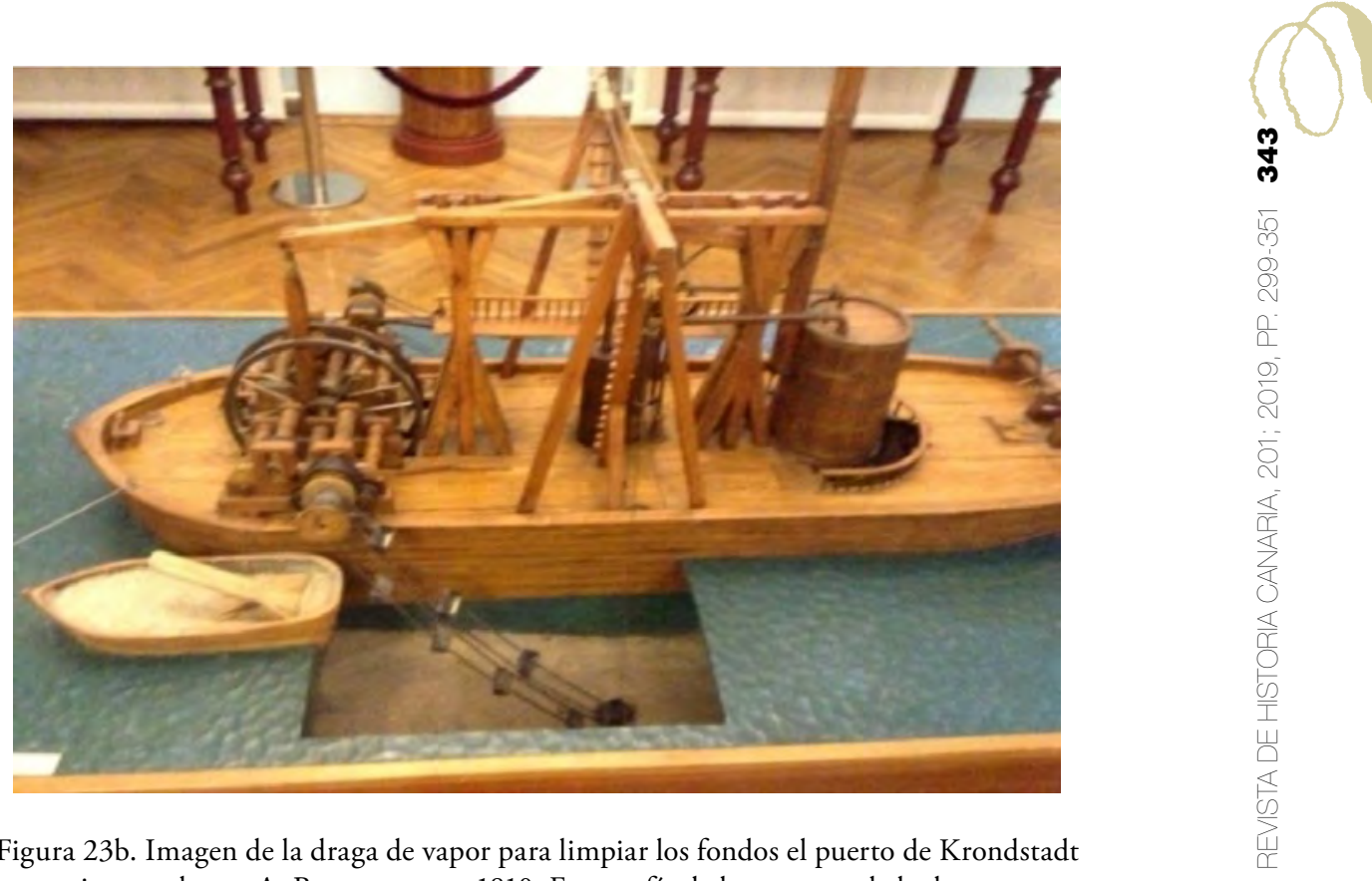
inventada por A. Betancourt en 1810. Fotografía de la maqueta de la draga de Krondstad del Museo de A. Betancourt en la Universidad Estatal de Vías de Comunicación de San Petersburgo. Fuente: Autoría propia. 


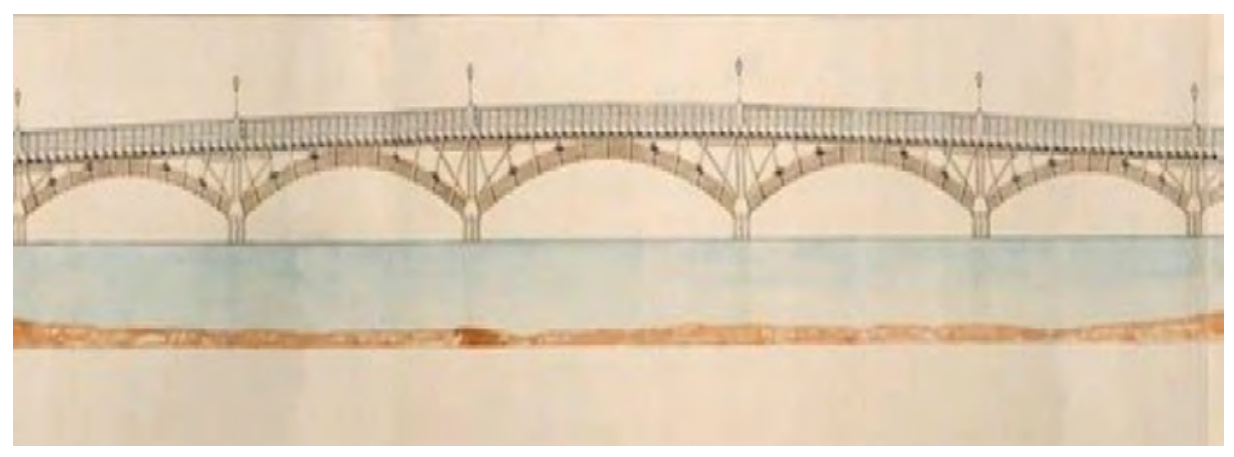

Figura 24. Plano del puente Kamennoostroski, diseñado por A. Betancourt en 1811. Fuente: http://www.fundacionorotava.es/betancourt/biography/3/.

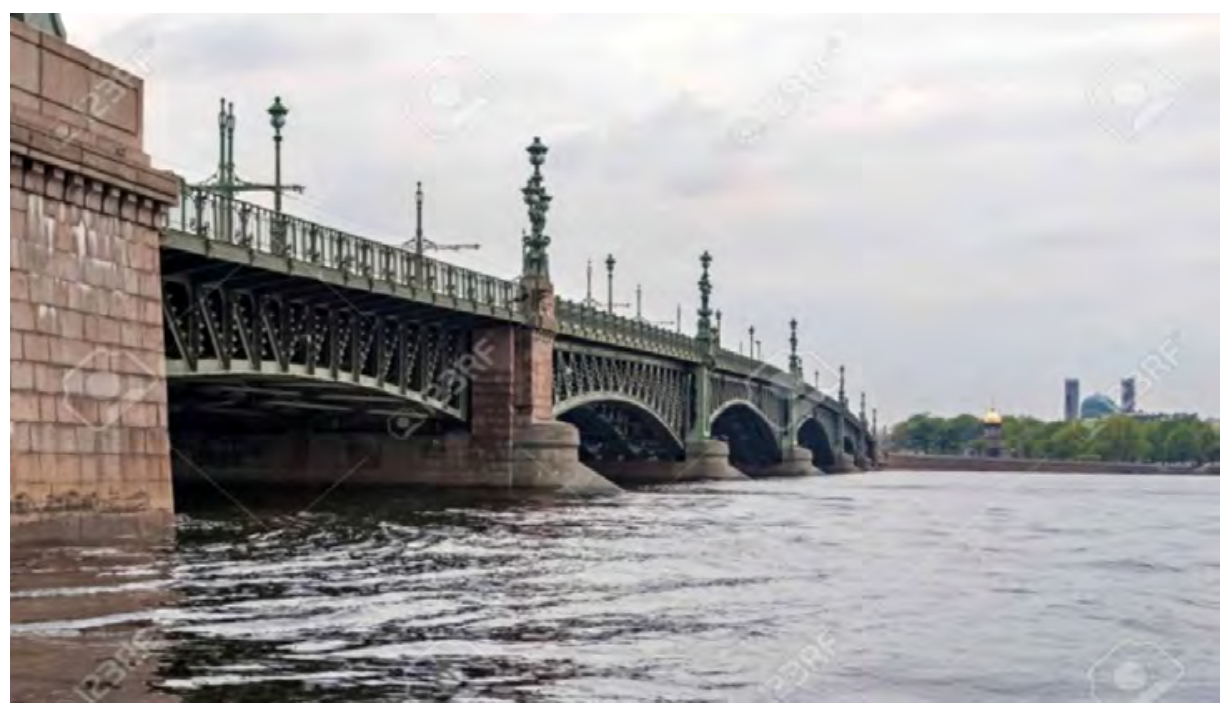

Figura 25. El puente actual Kamennoostroski, reconstruido en 1954.

Fuente: http://www.google.es/search?q=puente+kamennostroski+san+petersburgo+imagen. 


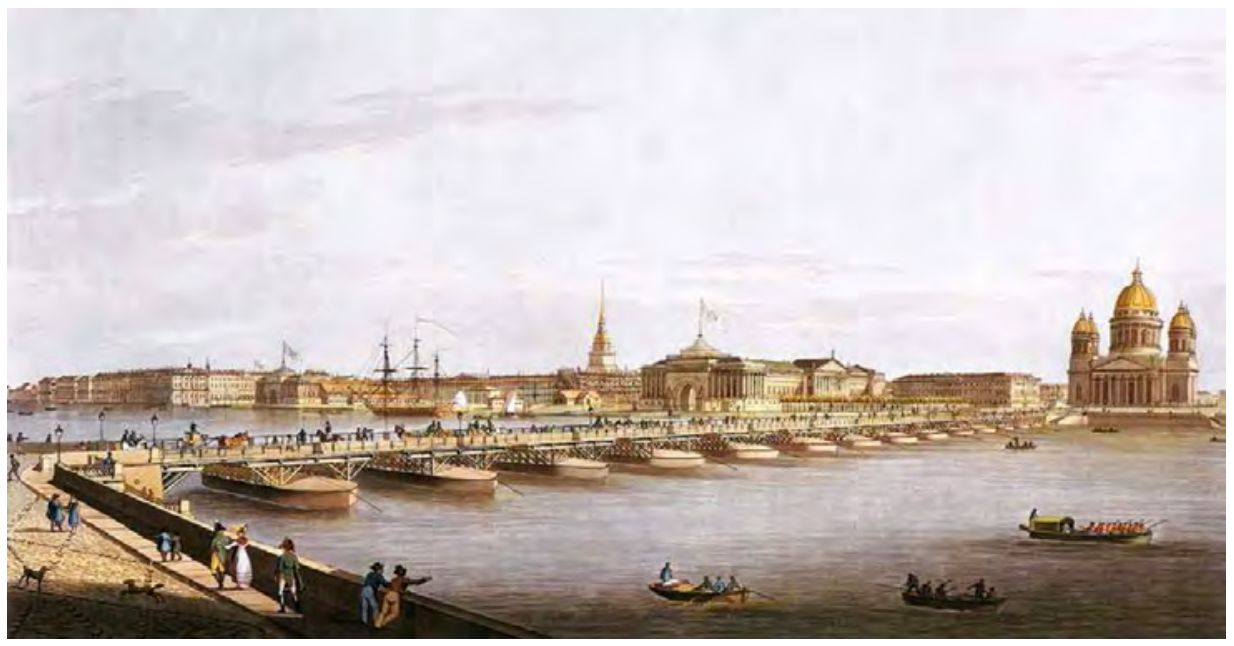

Figura 26. Puente de San Isaac sobre barcazas, de A. Betancourt, en 1820.

Fuente: http://www.alamy.es/vista-del-puente-de-san-isaac-en-san-petersburgo-1824-colecc.

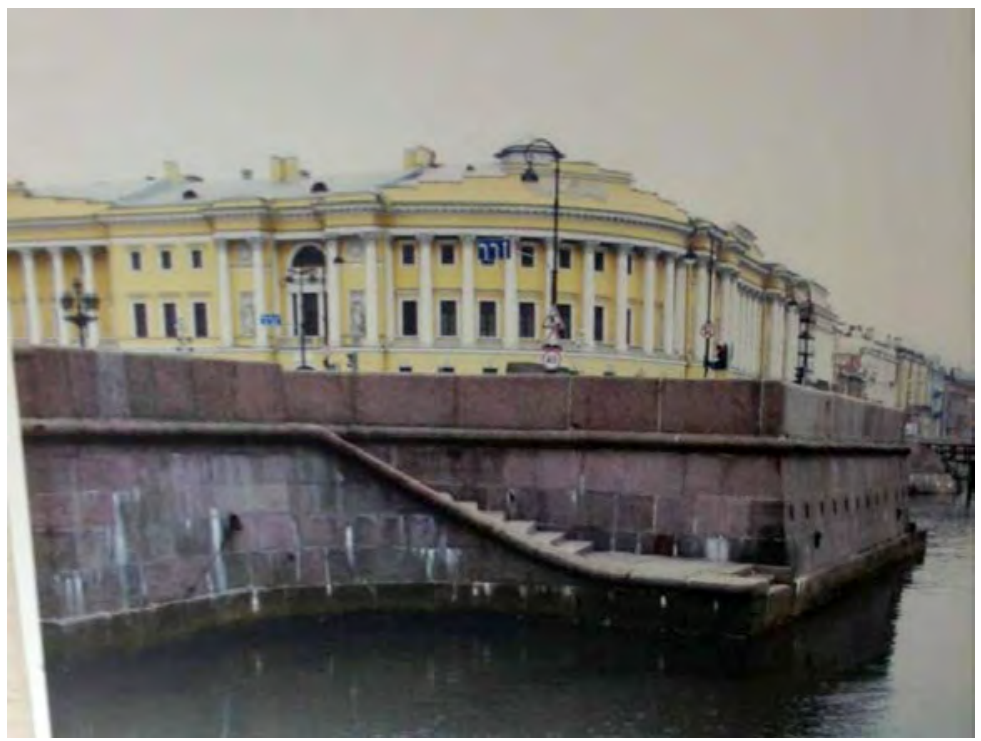

Figuras 27. Embarcadero con escaleras, que descendían hasta el nivel del agua en la orilla del puente de San Isaac junto a la plaza del Senado, diseñado por Agustín de Betancourt en 1820. Fuente: Museo del Ferrocarril de San Petersburgo. 


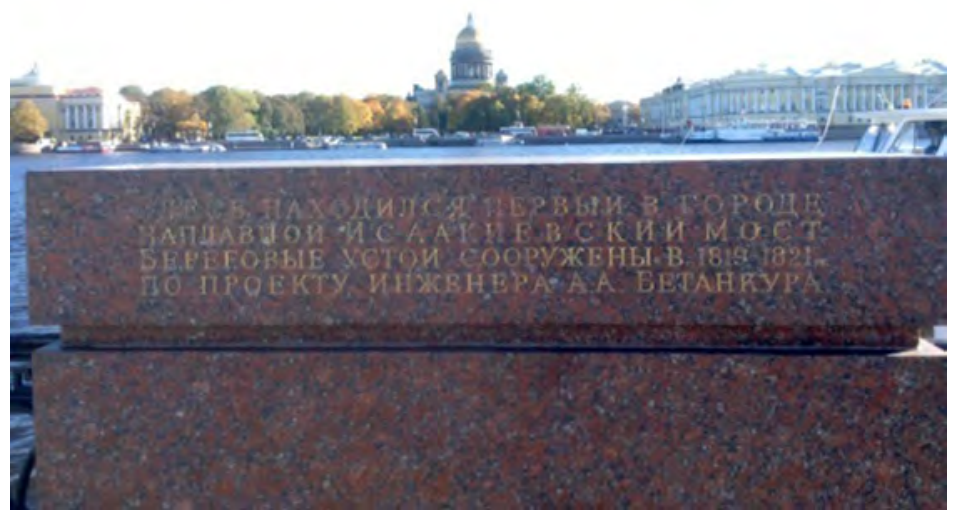

Figura 28. Piedra de granito rojo que recuerda dónde arrancaba el puente de San Isaac en la isla Vasilievski. Fuente: Fotografía de autoría propia.

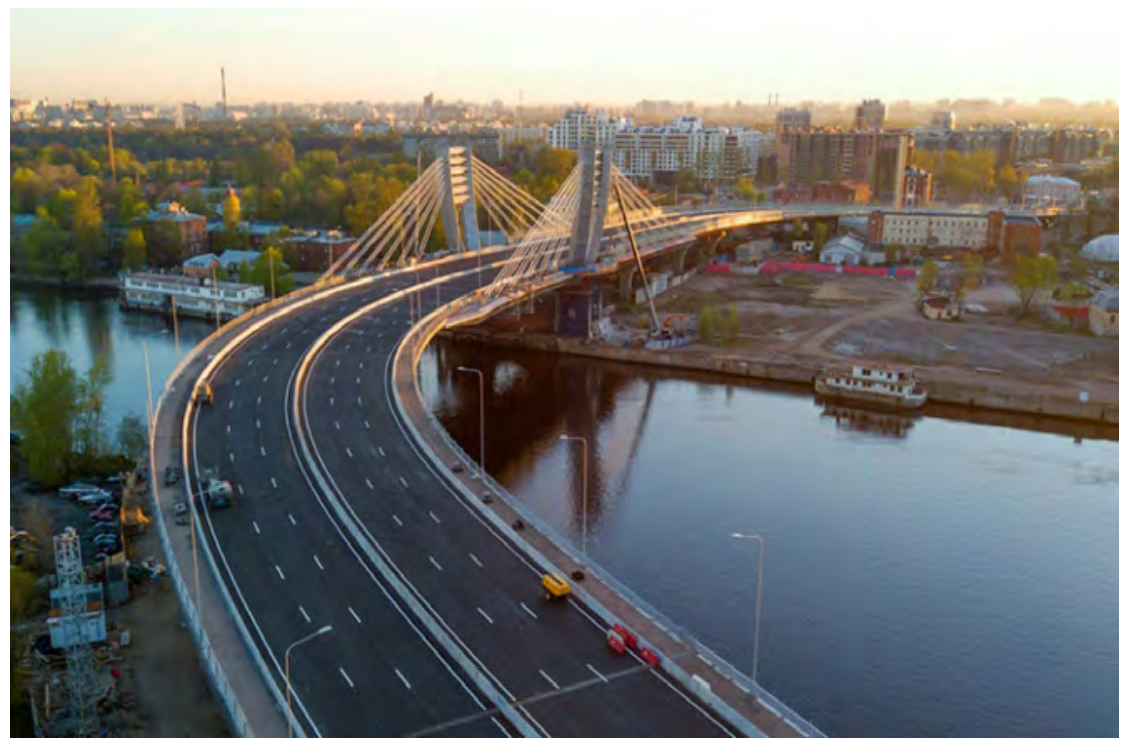

Figura 29. Fotografía del nuevo puente dedicado a A. Betancourt, mayo de 2018. Une las islas Petrovski, Serni y la de Dekabrístov a través del Málaia Neva de San Petersburgo. Fuente: https://cdni.rbth.com/rbthmedia/images/2018.05/article/5af98f8615e9f94aac53f125.jpg. 


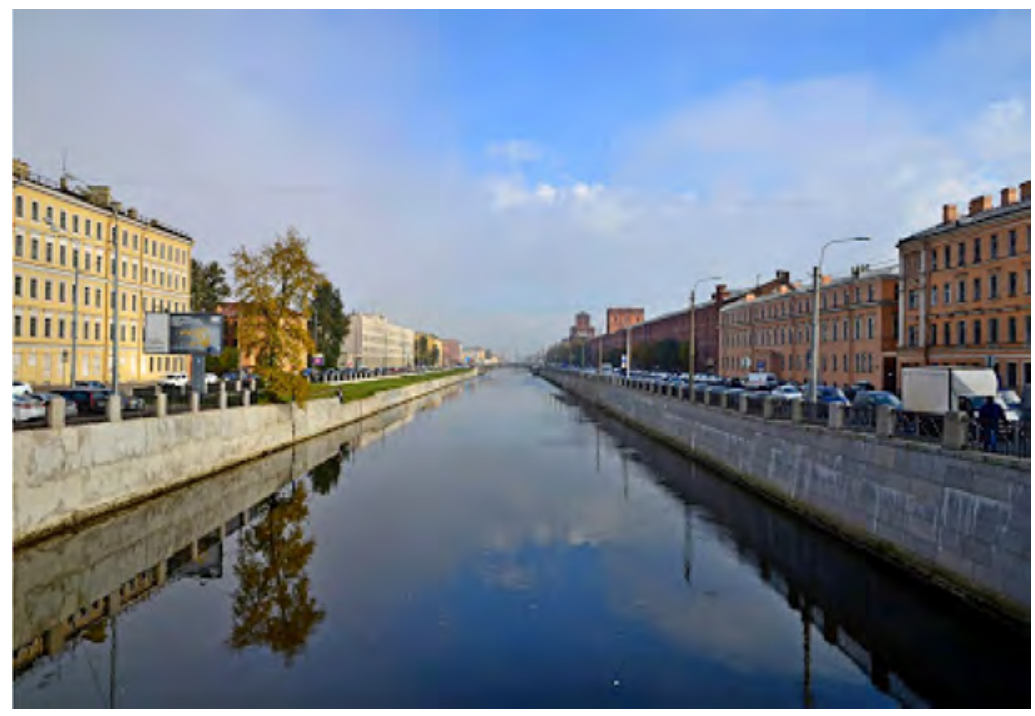

Figura 30. Canal Obvodny construido por A. Betancourt y De Wolant en 1816. De ocho kilómetros de longitud. Fuente: http://www.wikiwand.com/en/.

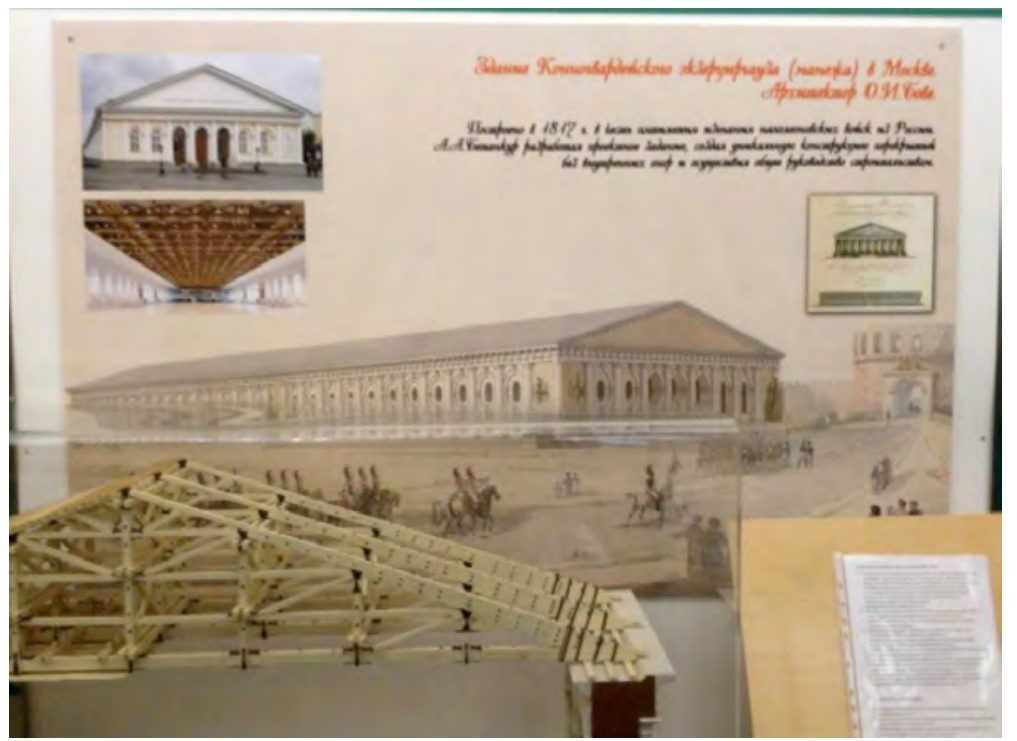

Figura 31. Imágenes de la Sala de Ejercicios Ecuestres (Manezh) de Moscú en 1817 por A. Betancourt. Fuente: Museo del Ferrocarril de San Petersburgo. 


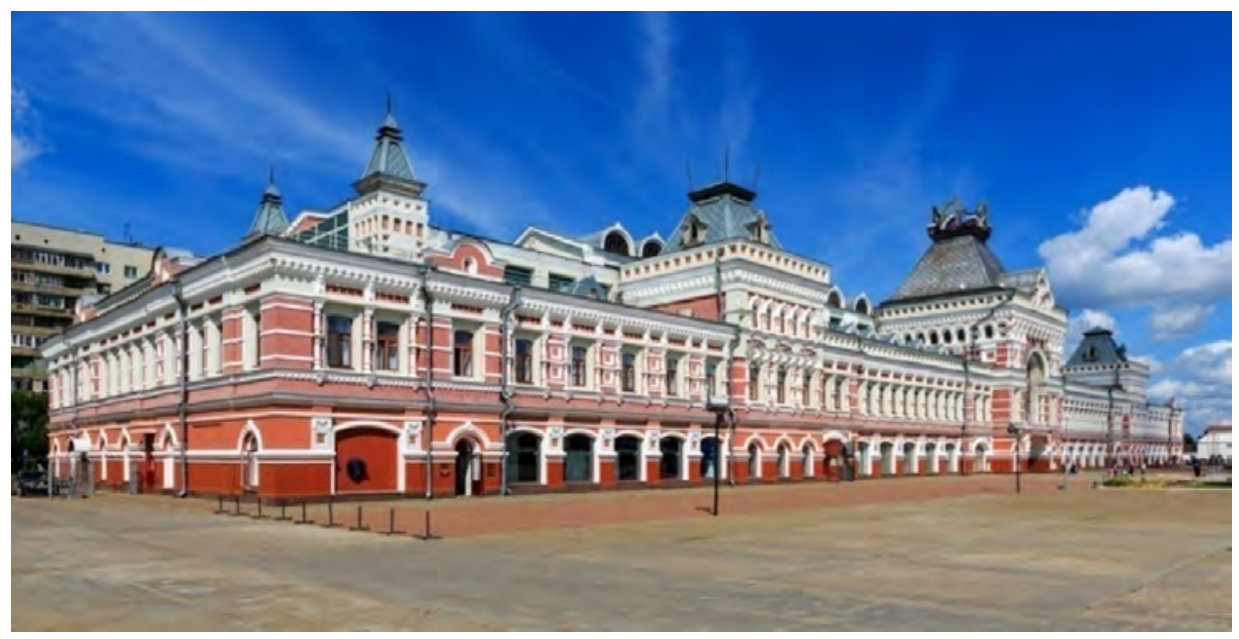

Figura 32. La gran obra de A. Betancourt. La Feria de Nizhni Novgorod, 1822.

Fuente: https://commons.m.wikimedia.org/wiki/File:NN_Trade_Fair_08-2016_img2.jpg.

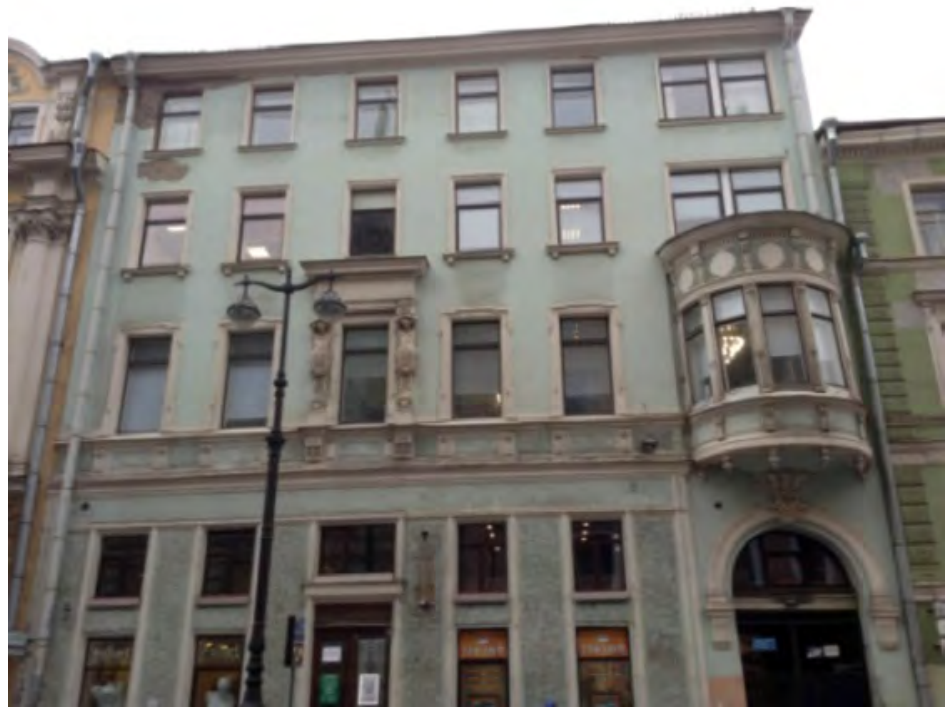

Figura 33. Última casa donde vivió A. Betancourt en San Petersburgo, de 1822 a 1824. Fuente: Fotografía de autoría propia. 


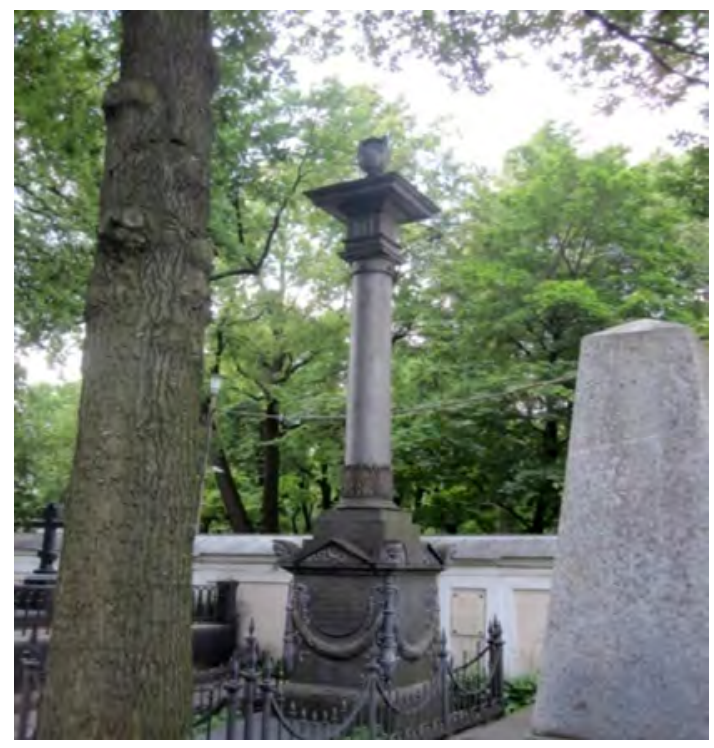

Figura 34. Tumba de Agustín de Betancourt en el cementerio «Lazareski», monasterio de San Alejandro Nevski de San Petersburgo.

Fuente: https://practicabloguned.wordpress.com/.

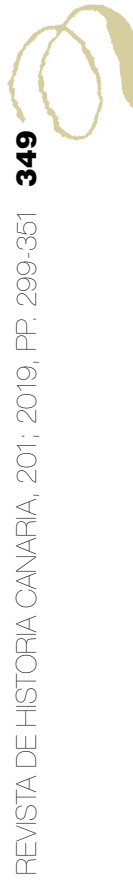




\section{FUENTES MANUSCRITAS}

Archivo Herederos Betancourt-Castro. AHBC (La Orotava-Tenerife).

AHBC, Leg. 9325. Carta n. ${ }^{\circ}$.

AHBC, Leg. 9327. Carta n. ${ }^{\circ} 11$.

AHBC, Leg. 9370. Carta n. ${ }^{\circ} 31$.

AHBC, Leg. 9540. Carta n. 37.

AHBC, Leg. 9542. Carta n. ${ }^{\circ} 38$.

AHBC. Leg. 9406. Carta n. ${ }^{\circ} 41$.

AHN. Estado, Leg. 4088/9, Exp. 10.

\section{FUENTES IMPRESAS}

Betancourt y Castro, José (1842): Noticias biográficas de Don Agustín de Betancourty Molina escritas por su sobrino carnal Don José de Betancourt y Castro de 1842. La Orotava de Tenerife. AHBC.

Fernández-Armesto, Felipe (1981): «Nueva aportación documental sobre Agustín de Betancourt y Molina y su familia». Anuario de Estudios Atlánticos. Madrid-Las Palmas, n. ${ }^{\circ}$ 27, pp. 239-260.

Mendía, Agustín (1849): Dos años en Rusia, obra redactada a la vista de las memorias y manuscritos originales del general Don Juan Van Halen. Imprenta de don José Mateu Garín: Valencia.

Montferrand, Auguste de (1845): L'Église cathédrale de Saint-Isaac, description arquitecturale, pittoresque et historique. San Petersburgo.

Biblioteca pública de san Petersburgo, Sección de Manuscritos. Journal des travaux de l'Église d'Isaac.

Biblioteca del instituto de ingenieros del transporte de Rusia. Bosquejo del proyecto de la Plaza de Invierno por Agustín de Betancourt.

Journal des Voies de Communication, I, 1826.

Historic Centre of Saint Petersburg and Related Groups of Monuments. UnesCO Culture Sector.

Museo Betancourt. Universidad Estatal del Transporte de San Petersburgo.

\section{REFERENCIAS DE INTERNET}

Fundación Canaria Orotava Historia de la Ciencia: http://fundacionorotava.es/betancourt/.

http://fundacionorotava.es/betancourt/biography/.

http://fundacionorotava.es/portal/databases/books/.

https://historiaybiografias.com/sanpetesburgo/.

https://es.wikipedia.org/wiki/Historia_del_ferrocarril_en_Rusia. 
https://elpais.com/cultura/. «España y Rusia se unen para recordar al ingeniero ilustrado Agustín de Betancourt», en El Pais», 26 de marzo de 1996.

https://rusopedia.rt.com/personalidades/politicos/issue_269.html.

https://es.wipedia.orgwiki >Juan Va...

http://www.mcnbiografias.com/app-bio/do/show?key=alejandro-i-zar-de-rusia. Alejandro I Paulowitch, Zar de Rusia (1777-1825).

http://www.fundacionabetancourt.org/.

https://plus,google.com >posts.

https://historiaybiografia.com $>$ biografi.

http://rusopedia.rt.com/personalidades/politicos/issue_269.html.

https://es.rbth.com >cultura $>80786$-san...

https://journals.openedition.org/dht/1511.

https://es.wikipedia.org >qiki>Catedral...

http://www.panoramanumismatico.com >agust...

http://www.wikiwand.com/en/Obvodny_Kanal_(Saint_Petersburg_Metro). 
